National Water-Quality Assessment Program

\title{
An Overview Comparing Results from Two Decades of Monitoring for Pesticides in the Nation's Streams and Rivers, 1992-2001 and 2002-2011
}

Scientific Investigations Report 2014-5154 



\section{An Overview Comparing Results from Two Decades of Monitoring for Pesticides in the Nation's Streams and Rivers, 1992-2001 and 2002-2011}

By Wesley W. Stone, Robert J. Gilliom, and Jeffrey D. Martin

National Water-Quality Assessment Program

Scientific Investigations Report 2014-5154 


\title{
U.S. Department of the Interior SALLY JEWELL, Secretary
}

\section{U.S. Geological Survey \\ Suzette M. Kimball, Acting Director}

\author{
U.S. Geological Survey, Reston, Virginia: 2014
}

For more information on the USGS - the Federal source for science about the Earth, its natural and living resources, natural hazards, and the environment, visit http://www.usgs.gov or call 1-888-ASK-USGS.

For an overview of USGS information products, including maps, imagery, and publications, visit http://www.usgs.gov/pubprod

To order this and other USGS information products, visit http://store.usgs.gov

Any use of trade, firm, or product names is for descriptive purposes only and does not imply endorsement by the U.S. Government.

Although this information product, for the most part, is in the public domain, it also may contain copyrighted materials as noted in the text. Permission to reproduce copyrighted items must be secured from the copyright owner.

Suggested citation:

Stone, W.W., Gilliom, R.J., and Martin, J.D., 2014, An overview comparing results from two decades of monitoring for pesticides in the Nation's streams and Rrvers, 1992-2001 and 2002-2011: U.S. Geological Survey Scientific Investigations Report 2014-5154, 23 p., http://dx.doi.org/10.3133/sir20145154.

ISSN 2328-0328 (online)

http://dx.doi.org/10.3133/sir20145154 


\section{Contents}

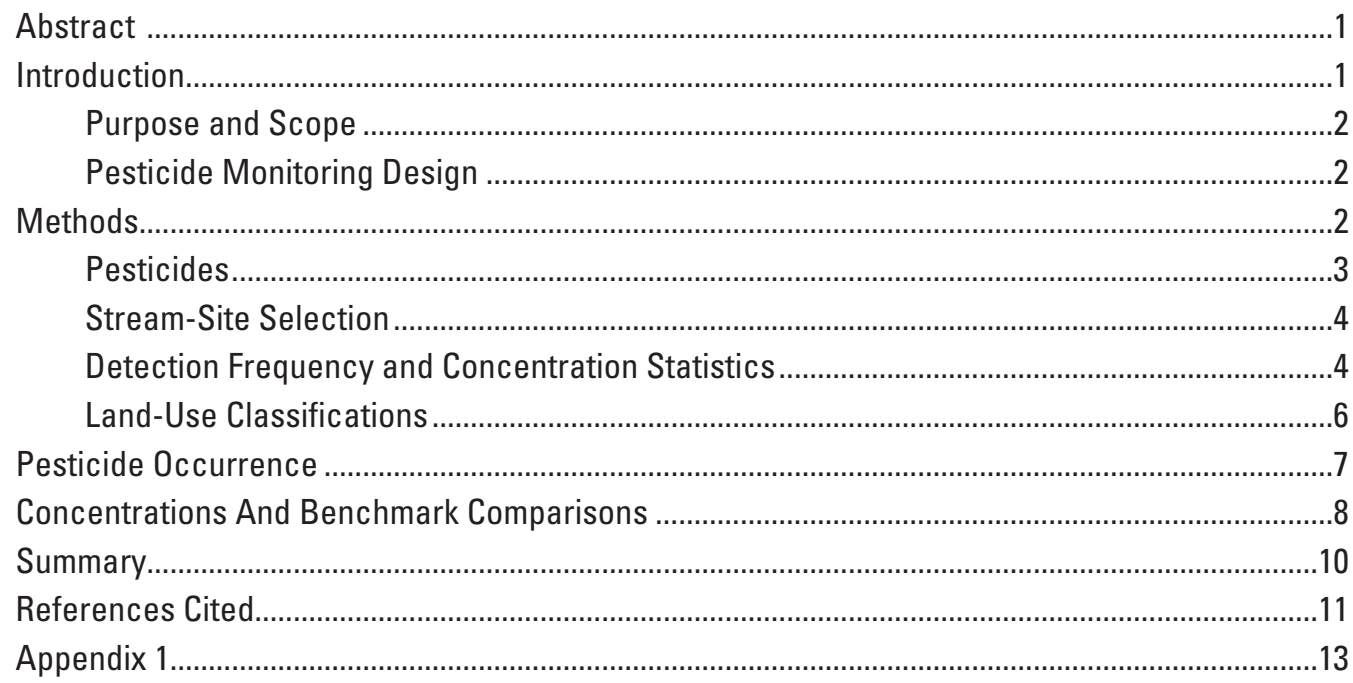

\section{Figures}

1. Estimated agricultural use of synthetic organic herbicides, insecticides, and fungicides in the conterminous U.S. during first (1992-2001) and second (2002-11) decades of stream monitoring...

2. Map showing the national monitoring network for pesticides in streams and rivers included 182 sites during 1992-2001 and 125 sites during 2002-11, with 96 of the sites common to both decades.

3. Percentage of time during a year that the most frequently detected pesticides were detected in streams and rivers in relation to land-use classification...

4. Pesticides that exceeded chronic Aquatic Life Benchmarks at more than 5 percent of stream sites and percent of streams by land-use classification

\section{Tables}

1. Minimum samples, per water year, by watershed size .......................................................

2. Land-use classifications and watershed land-use criteria .......................................................6

3. Number of stream sites by land-use classific ation .......................................................

4. Percent of time one or more pesticides or pesticide degradates were detected in streams, by land-use classification ................................................................................

5. Percent of streams with one or more pesticide concentration statistics that exceeded a chronic Aquatic Life Benchmark (ALB), by land-use classification ............10 


\section{Conversion Factors and Abbreviations}

SI to Inch/Pound

\begin{tabular}{ccl}
\hline Multiply & \multicolumn{1}{c}{ By } & \multicolumn{1}{c}{ To obtain } \\
\hline \multicolumn{2}{c}{ Area } & \\
\hline square kilometer $\left(\mathrm{km}^{2}\right)$ & 247.1 & acre \\
square kilometer $\left(\mathrm{km}^{2}\right)$ & 0.3861 & square mile $\left(\mathrm{mi}^{2}\right)$ \\
\hline
\end{tabular}

Water year is the 12-month period of October 1, for any given year through September 30, of the following year. The water year is designated by the calendar year in which it ends and which includes 9 of the 12 months.

\section{Abbreviations used in this report}

$\begin{array}{ll}\text { ALB } & \text { Aquatic Life Benchmark } \\ \text { GCMS } & \text { gas chromatography/mass spectrometry } \\ \text { HHB } & \text { Human Health Benchmark } \\ \text { NASQAN } & \text { National Stream Quality Accounting Network } \\ \text { NAWQA } & \text { National Water-Quality Assessment } \\ \text { NLCD } & \text { National Land Cover Data } \\ \text { NLCD06 } & \text { National Land Cover Data 2006 } \\ \text { NLCDe } & \text { National Land Cover Data enhanced } \\ \text { NWOL } & \text { National Water Quality Laboratory } \\ \text { USGS } & \text { U.S. Geological Survey }\end{array}$




\title{
An Overview Comparing Results from Two Decades of Monitoring for Pesticides in the Nation's Streams and Rivers, 1992-2001 and 2002-2011
}

\author{
By Wesley W. Stone, Robert J. Gilliom, and Jeffrey D. Martin
}

\section{Abstract}

This report provides an overview of the U.S. Geological Survey National Water-Quality Assessment program and National Stream Quality Accounting Network findings for pesticide occurrence in U.S. streams and rivers during 2002-11 and compares them to findings for the previous decade (1992-2001). In addition, pesticide stream concentrations were compared to Human Health Benchmarks (HHBs) and chronic Aquatic Life Benchmarks (ALBs). The comparisons between the decades were intended to be simple and descriptive. Trends over time are being evaluated separately in a series of studies involving rigorous trend analysis. During both decades, one or more pesticides or pesticide degradates were detected more than 90 percent of the time in streams across all types of land uses. For individual pesticides during 2002-11, atrazine (and degradate, deethylatrazine), carbaryl, fipronil (and degradates), metolachlor, prometon, and simazine were detected in streams more than 50 percent of the time. In contrast, alachlor, chlorpyrifos, cyanazine, diazinon, EPTC, Dacthal, and tebuthiuron were detected less frequently in streams during the second decade than during the first decade. During 2002-11, only one stream had an annual mean pesticide concentration that exceeded an HHB. In contrast, 17 percent of agriculture land-use streams and one mixed land-use stream had annual mean pesticide concentrations that exceeded HHBs during 1992-2001. The difference between the first and second decades in terms of percent of streams exceeding HHBs was attributed to regulatory changes. During 2002-11, nearly two-thirds of agriculture land-use streams and nearly onehalf of mixed land-use streams exceeded chronic ALBs. For urban land use, 90 percent of the streams exceeded a chronic ALB. Fipronil, metolachlor, malathion, cis-permethrin, and dichlorvos exceeded chronic ALBs for more than 10 percent of the streams. For agriculture and mixed land-use streams, the overall percent of streams that exceeded a chronic ALB was very similar between the decades. For urban land-use streams, the percent of streams exceeding a chronic ALB during
2002-11 nearly doubled that seen during 1992-2001. The reason for this difference was the inclusion of fipronil monitoring during the second decade. Across all land-use streams, the percent of streams exceeding a chronic ALB for fipronil during 2002-11 was greater than all other insecticides during both decades. The percent of streams exceeding a chronic ALB for metolachlor, chlorpyrifos, diazinon, malathion, and carbaryl decreased from the first decade to the second decade. The results of the 2002-11 summary and comparison to 1992-2001 are consistent with the results from more rigorous trend analysis of pesticide stream concentrations for individual streams in various regions of the U.S.

\section{Introduction}

The U.S. Geological Survey (USGS) National WaterQuality Assessment (NAWQA) and National Stream Quality Accounting Network (NASQAN) are monitoring programs that collect and report data for national assessments of pesticide concentrations in the Nation's streams and rivers. Gilliom and others (2006) reported findings for the first decade (19922001) of the NAWQA program and found that pesticides or their degradates were present in one or more water samples from every stream included in the assessment; one or more pesticides were detected more than 90 percent of the time in agricultural, urban, and mixed land-use streams; and the most frequently detected pesticides also had the greatest use.

This report builds upon the 1992-2001 assessment of pesticides in the Nation's streams (Gilliom and others, 2006) by summarizing pesticide occurrence in streams during the second decade (2002-11) of NAWQA stream monitoring, including pesticide stream concentration data from the NASQAN program, and providing descriptive comparisons between the two decades of pesticide monitoring. Gilliom and others (2006) assessed the occurrence of 83 pesticides and degradates from 186 stream sites that represented agriculture, urban, mixed, and undeveloped land uses during 1992-2001. 
Changes in the NAWQA program between the first and second decades reduced the number of monitored stream sites. The sampling design (number of samples to be collected and when they were to be collected) also changed between the decades. Specifically, the 1992-2001 sampling design was a mix of fixed-frequency sampling and high-flow sampling (to characterize times of expected higher stream pesticide concentrations); however, the 2002-11 sampling design was fixed-frequency with minimal high-flow sampling efforts. In addition, the number of pesticides and degradates that were monitored in streams sufficient for a national assessment nearly doubled during the second decade.

The changes in the NAWQA pesticide stream monitoring program from the first to second decade made it difficult to do simple, stream site to stream site comparisons between the decades and compare directly to the assessment by Gilliom and others (2006). In addition, this assessment differs from the previous assessment by Gilliom and others (2006) because (1) Human Health Benchmarks (HHBs) and chronic Aquatic Life Benchmarks (ALBs) have been updated; (2) some pesticides assessed during 1992-2001 were not sampled at enough sites to attain a reasonable national distribution during 2002-11; (3) land use ancillary data used to group sites have changed over time; (4) the stream-site selection process was revised; and (5) this assessment includes multiple years of data for sites, when available. The inclusion of multiple years of concentration data rather than a single year in the assessment, as was done by Gilliom and others (2006), was evaluated in terms of occurrence and percent of stream sites exceeding an HHB or chronic ALB for 1992-2001. The occurrence of pesticides in streams and the percent of stream sites that exceeded an HHB or chronic ALB for a single year compared to multiple years were all within 10 percent of each other for 1992-2001. Overall, the 1992-2001 results in this report are not markedly different than those reported by Gilliom and others (2006) except in cases where an ALB has been more recently established. For example, an ALB for metolachlor or $S$-metolachlor did not exist when Gilliom and others (2006) completed the initial assessment for 1992-2001; however, ALBs for $S$-metolachlor have been established and are used in this assessment. This report uses the most current HHBs and chronic ALBs for assessment of annual pesticide stream concentrations. Acute ALBs were not used in the comparisons between decades because the differences in sampling designs between them would likely bias the comparisons.

\section{Purpose and Scope}

The purpose of this report is to summarize pesticide occurrence in U.S. streams and rivers during 2002-11 in comparison to the previous decade, 1992-2001. This overview focuses on pesticide occurrence (percent of time detected) and pesticide concentrations in relation to HHBs and chronic ALBs. Although pesticide occurrence is compared between the decades for perspective, the comparisons are simple and descriptive, and are not meant as a rigorous trend analysis. Trends are being evaluated separately in a series of studies involving quantitative site-based trend models, including Corn-Belt streams (Sullivan and others, 2009) and urban streams (Ryberg and others, 2010).

\section{Pesticide Monitoring Design}

The national design for monitoring pesticides in streams and rivers has evolved from the combination of two USGS programs, NAWQA and NASQAN. NAWQA stream monitoring during 1992-2001 focused on assessing water-quality conditions in 51 of the Nation's river basins, referred to as "Study Units," on a rotational schedule — 20 Study Units during 199295, 16 during 1996-98, and 15 during 1998-2001 (Gilliom and others, 2006). Pesticide samples generally were collected at each stream site by using a combination of fixed-frequency and high-flow sampling (Gilliom and others, 1995). Fixedfrequency sampling means that a given number of waterquality samples were allocated to each month (more samples for months with expected higher potential for pesticide runoff and fewer samples during months of lower expected potential for pesticide runoff), and the water samples were collected at regularly spaced intervals within each month. High-flow sampling was used to allocate additional water samples to characterize high-flow events during seasonal periods of high pesticide use and potential runoff. Changes to the design of the NAWQA program during 2002-2011 included reduction in the number of long-term stream-monitoring sites, an increased emphasis on regional assessments, and supplemental highflow sampling was limited to special regional studies.

The NASQAN program was redesigned in 1995 to estimate the mass flux of pesticides and other constituents at 41 monitoring sites in four large river systems: the Mississippi, the Rio Grande, the Columbia, and the Colorado. Similar to the NAWQA program, water samples generally were collected at each stream site by using a combination of fixed-frequency and high-flow sampling (Hooper and others, 2001). Also similar to the NAWQA program, the frequency of waterquality sampling typically changed seasonally, with more frequent samples during the peak pesticide-runoff months. The NASQAN sampling strategy was revised in 2000 (U.S. Geological Survey, 2010), with reduced monitoring in the Columbia and Colorado River Basins.

\section{Methods}

This report summarizes pesticide stream concentration data from samples collected during 2002-11 and compares the results to findings from 1992-2001. Site selection was based on the number of years with data, watershed size, and frequency of sampling within each year. For a sampling site, all years of sampling that met the minimum sampling criteria were included in the summaries. The summaries for 
both decades are based on the estimated amount of time a pesticide was detectable at a stream site and the number of times HHBs and chronic ALBs were exceeded. For summary purposes, sampling sites were grouped by dominant land-use classification.

\section{Pesticides}

During any given year more than 400 different pesticides are used in agricultural settings (Stone, 2013). The large number of pesticides in use and the phasing out and introduction of new pesticides make it not possible to monitor all pesticides because of budget and method constraints. This report includes a selected subset of pesticides in use over the last two decades that were sampled at enough sites to attain a reasonable national distribution during 2002-11.

Pesticides included in this report are listed in appendix 1 (table 1-1). Martin (2009) determined that only pesticide data from a single laboratory and analytical method were sufficiently extensive in time and space for a national assessment across decades. Hence, only pesticides and pesticide data that were analyzed at the National Water-Quality Laboratory (NWQL) by a gas chromatography/mass spectrometry (GCMS) method were included in this report. The NAWQA and NASQAN programs periodically evaluate the full range of pesticides in use to prioritize monitoring to include the most important ones in relation to ecosystem and human health (Norman and others, 2012). This prioritization process also evaluates the likelihood that a pesticide will be found in surface water or sediment, based on chemical properties. During
2002-11, there were 123 pesticides and pesticide degradates with sufficient stream concentration data to include in this assessment. Gilliom and others (2006) included 83 pesticides in their assessment of 1992-2001; however, only 47 of these pesticides were sampled at enough sites during 2002-11 for a national-level comparison between the decades. The difference between the 47 pesticides assessed during the first decade and the 123 pesticides assessed during the second decade included 39 (or 51 percent) pesticide degradates; 21 (or 28 percent) insecticides; 8 (or 11 percent) fungicides; and the remaining were herbicides, nematicides, plant growth regulators, and defoliants.

Figure 1 shows an overview by one measure-amount used - of how pesticides included in this report relate to total national use and to selected pesticides or groups not included. A large portion of the difference between national total herbicide use and the proportion included in this report was the result of increased use of glyphosate that came with the rapid adoption of genetically modified crops resistant to glyphosate, beginning in the mid-1990s. Glyphosate is difficult and costly to measure, and efforts to assess glyphosate have been limited primarily to local or short-term studies. Other types of pesticides not comprehensively included in this report, such as fungicides and neonicotinoid insecticides, are not individually as prominent as glyphosate in terms of amounts applied, but may be environmentally important because of their greater toxicity. Finally, some hydrophobic pesticides, such as legacy organochlorines and pyrethroid insecticides, are important as contaminants of sediment and (or) tissues, but are not often found in filtered-water samples.

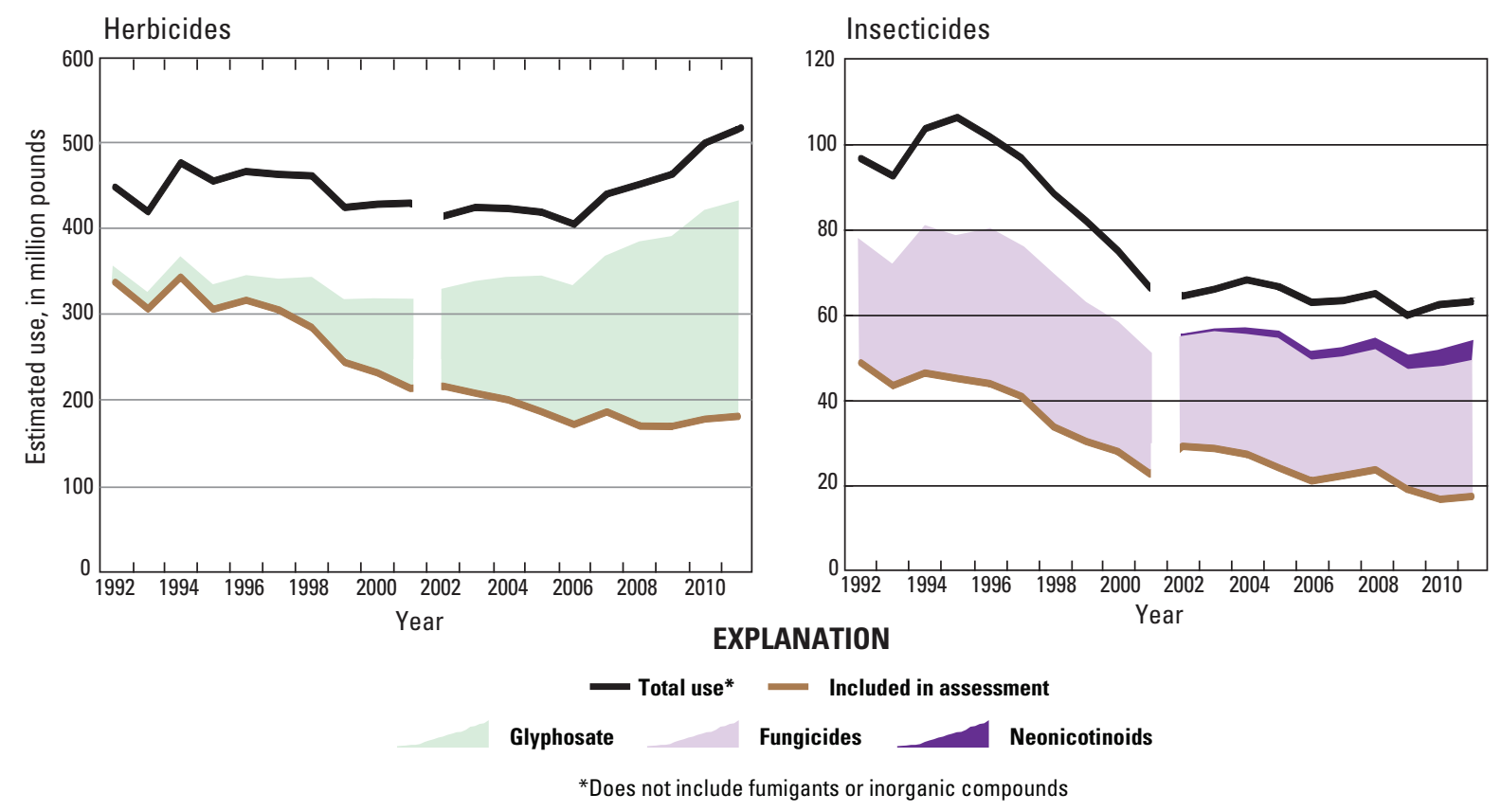

Figure 1. Estimated agricultural use of synthetic organic herbicides, insecticides, and fungicides in the conterminous U.S. during first (1992-2001) and second (2002-11) decades of stream monitoring. (GfK Kynetec, Inc., proprietary data, written commun., December 2011 and July 2013). 


\section{Stream-Site Selection}

Stream-site selection was based on total number of samples each year, watershed size, and the number of samples during potentially high pesticide runoff months. A year was defined as the water year, beginning October 1 and ending September 30. Stream-site selection was based on modification of the criteria used in Stone and others (2013). The stream-site selection process began with an evaluation of the number of samples collected for the water year compared to minimums based on watershed size (table 1). Stream sites retained from the previous step were then evaluated to make sure there was at least one sample during the months of May, June, and July. These three months are typically the months of expected higher transport of pesticides to streams for the most heavily used pesticides (Stone and others, 2013). Stream sites retained to this point were then evaluated to ensure that samples were present during times when pesticides are less likely transported to streams in order to better represent their occurrence during the entire water year. Specifically, each stream site could not have a consecutive 3-month period without a sample. The stream-site selection process was done by individual pesticide because changing analysis schedules over time caused variations in sample numbers between pesticides for some years. The stream-site selection process also did not limit the selection to a single year; all years of sampling at a stream site that met the selection criteria were included in this summary. Stream sites selected for the summary are shown in figure 2 and listed in appendix 1 (table 1-2).

Table 1. Minimum samples, per water year, by watershed size.

$\left[\mathrm{km}^{2}\right.$, square kilometer; water year, the 12-month period of October 1, for any given year through September 30, of the following year. The water year is designated by the calendar year in which it ends and which includes 9 of the 12 months]

\begin{tabular}{lc}
\hline \multicolumn{1}{c}{ Watershed size $\left.\mathbf{( k m}^{2}\right)$} & Minimum number of samples \\
\hline Less than 500 & 16 \\
500 to 4,999 & 12 \\
5,000 to 50,000 & 10 \\
Greater than 50,000 & 8 \\
\hline
\end{tabular}

\section{Detection Frequency and Concentration Statistics}

Time-weighted detection frequencies account for the more frequent sample collection during some months than in other months and provide an estimate of the percentage of time (throughout the water year) that a pesticide was detected. The weights were calculated as the amount of time extending from one-half the time interval between an observation and the preceding observation and one-half the time interval extending from the observation to the subsequent observation, divided by the total time in one year. Sample weights for a pesticide at a stream site sum to one for each year; therefore, the sum of the weights for samples with detections represent the percentage of time that pesticide was detected for that stream site and year. When there were multiple water years for a stream site and pesticide, the median percentage of time detected across the years was used for that stream site and pesticide. Both the mean and median were evaluated for sites and pesticides with multiple water years of data, and there was not a large difference between the two statistics for the sites and pesticides used in this summary.

Annual concentration statistics were calculated for each stream site and pesticide for comparison to HHBs (Toccalino and others, 2014) and chronic ALBs (U.S. Environmental Protection Agency Office of Pesticide Program, http://www. epa.gov/oppefed1/ecorisk_ders/aquatic_life_benchmark.htm, accessed July 2013). Specifically, the annual mean concentration for comparison to HHBs, the annual maximum 21-day moving-average concentration for comparison to the chronic invertebrate ALBs, and the annual maximum 60-day movingaverage concentration for comparison to chronic fish and chronic aquatic community (atrazine) ALBs were calculated for this comparison.

Annual mean pesticide concentrations were calculated following the methods described in Larson and others (2004). Specifically, each observed concentration was weighted according to the amount of time it was used to represent the pesticide concentration in the stream. The weights were calculated as the amount of time extending from one-half the time interval between an observation and the preceding observation and one-half the time interval extending from the observation to the subsequent observation, divided by the total time in 1 year. Censored observations complicate the calculation of annual mean concentrations. As described in Larson and others (2004), if less than 10 percent of the weighted data for a site, pesticide, and year combination were censored, censored observations were replaced by one-half the censoring threshold reported by the laboratory. If more than 10 percent of the weighted data were censored, and there were at least 20 annual observations with at least 10 uncensored observations and at least 33 percent of the sample weights were represented by uncensored observations, then the log-regression method (Gilliom and Helsel, 1986; Helsel and Gilliom, 1986) was used to approximate the annual mean concentration. Otherwise, the annual mean concentration was considered to be censored at the censoring threshold reported by the laboratory. For stream sites and pesticides with multiple years of data, if an HHB was exceeded for a pesticide in any year during the first or second decade then the HHB was considered exceeded for that stream site and pesticide in the respective decade.

Annual maximum moving-average pesticide concentrations were calculated following the methods described in Stone and others (2008). Hourly pesticide concentrations were estimated for each stream site through linear interpolation of actual observations. Censored observations were assigned a value of zero for the process of linear interpolation. The hourly concentration estimates were averaged to obtain an 


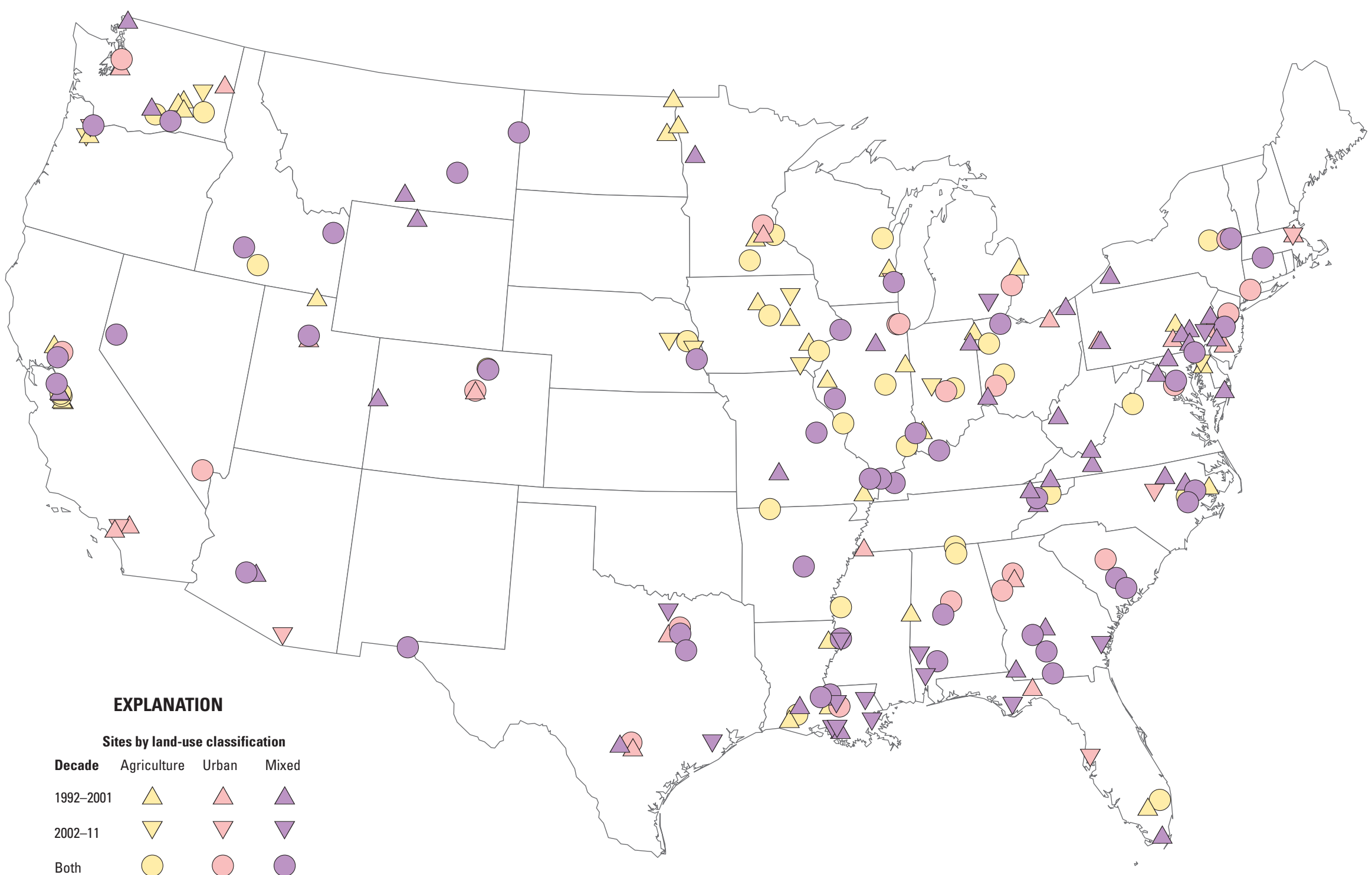

Figure 2. The national monitoring network for pesticides in streams and rivers included 182 sites during 1992-2001 and 125 sites during 2002-11, with 96 of the sites common to both decades. 
estimated daily concentration. The hourly estimates facilitated computations for days with multiple samples but were not used for other purposes. Moving-average concentrations for the selected durations ( 21 and 60 days) were computed for each day. The annual maximum moving-average pesticide concentrations for each duration were then determined for each stream site/year combination meeting the selection criteria. In most cases, insufficient observations were available for stream sites to calculate moving-average concentrations (21- or 60-day durations) for the beginning of the selected year used in the summary. For example, if the selected year for a stream site was 1993, and there were no observations available prior to that year. To address this issue and estimate movingaverage concentrations for the beginning of the selected year, the actual observations for the selected year for that stream site and pesticide were used as surrogate observations for the prior year. For stream sites and pesticides with multiple years of data, if a chronic ALB was exceeded for a pesticide in any year during the first or second decade then the chronic ALB was considered exceeded for that stream site and pesticide in the respective decade.

For discussion and illustration purposes, the percentage of time pesticides were detected in streams and percent of streams exceeding an HHB or chronic ALB were grouped by land-use classification, which is discussed in the subsequent section. The percentage of time a pesticide was detected in a stream for a land-use classification was normalized by the number of stream sites within that land-use classification to avoid one stream site having more influence than another in the summary.

\section{Land-Use Classifications}

The summaries and comparisons in this report group streams into three land-use classifications: agriculture, urban, and mixed. The land-use classifications and watershed landuse criteria are similar to those used in Gilliom and others (2006), with two modifications. First, the 2006 National Land Cover Data (NLCD06) was used to classify streams based on land use instead of the 1992 enhanced NLCD (NLCDe). Second, the amount of urban land use allowable in a watershed for the agriculture stream classification was increased from 5 to 10 percent because of the differences in methodology between NLCDe and NLCD06. In addition, Gilliom and others (2006) included streams with a land-use classification of undeveloped; however, this summary does not include streams with this land-use classification. The land-use classifications and watershed land-use criteria are shown in table 2. For some streams (fewer than 5 percent), the area within the watershed that contributed the majority of water to the stream was not reflective of the land use for the total watershed area. Differences between the total watershed area and the area contributing the majority of water to a stream can be caused by natural landscape variations and water-management practices. In these cases, the land-use classification for the stream was changed to reflect the land use for the area contributing the majority of water to the stream. The land-use classifications for each stream are shown in figure 2 and listed in appendix 1 (table 1-2). The number of stream sites by land-use classification is shown in table 3 .

Table 2. Land-use classifications and watershed land-use criteria.

\begin{tabular}{ll}
\hline \multicolumn{1}{c}{ Land-use classification } & \multicolumn{1}{c}{ Watershed land-use criteria } \\
\hline Agriculture & Greater than 50 percent agricultural land and less than or equal to 10 percent urban land \\
Urban & Greater than 25 percent urban land and less than or equal to 25 percent agricultural land \\
Undeveloped & Less than or equal to 5 percent urban land and less than or equal to 25 percent agriculture land \\
Mixed & All other combinations of agriculture, urban, and undeveloped land use \\
\hline
\end{tabular}

Table 3. Number of stream sites by land-use classification.

\begin{tabular}{lccc}
\hline Land-use classification & $\begin{array}{c}\text { Number } \\
\text { of stream sites } \\
\mathbf{1 9 9 2 - 2 0 0 1}\end{array}$ & $\begin{array}{c}\text { Number } \\
\text { of stream sites } \\
\mathbf{2 0 0 2 - 1 1}\end{array}$ & $\begin{array}{c}\text { Number of common } \\
\text { stream sites }\end{array}$ \\
\hline Agriculture & 59 & 36 & 28 \\
Mixed & 83 & 59 & 45 \\
Urban & 40 & 30 & 23 \\
Total & 182 & 125 & 96 \\
\hline
\end{tabular}




\section{Pesticide Occurrence}

One or more pesticides or pesticide degradates were detectable more than 90 percent of the time in streams across all land uses during 2001-11 (table 4). As mentioned previously, the data from this second decade included analysis of nearly twice as many pesticides and pesticide degradates than the first decade; however, the overall percent of time they

Table 4. Percent of time one or more pesticides or pesticide degradates were detected in streams, by land-use classification.

\begin{tabular}{lcc}
\hline Land-use classification & $\begin{array}{c}\text { Percent of time } \\
\text { detected for } \\
\text { 1992-2001 }\end{array}$ & $\begin{array}{c}\text { Percent of time } \\
\text { detected for } \\
\text { 2002-11 }\end{array}$ \\
\hline Agriculture & 98 & 95 \\
Mixed & 96 & 96 \\
Urban & 98 & 99 \\
\hline
\end{tabular}

were detected in streams was nearly the same for both decades (table 4). Variations in percent of time pesticides and pesticide degradates were detected in streams was more evident for individual compounds.

Figure 3 shows the percent of time individual compounds were detected in streams. For illustration purposes, only the top 20 most frequently detected pesticides and degradates by land-use classification and decade are shown. The top 20 most frequently detected are a composite of the top 10 most frequently detected from each land use/decade combination. Across all land-use classifications, the herbicides atrazine, deethylatrazine (atrazine degradate), metolachlor, and simazine were detected more than 50 percent of the time in streams during 2002-11 (fig. 3). The herbicide prometon was detected more than 50 percent of the time in mixed and urban land-use classification streams during 2002-11. The insecticides fipronil, fipronil sulfide (degradate), and carbaryl, were detected more than 50 percent of the time in urban land-use classification streams during 2002-11.

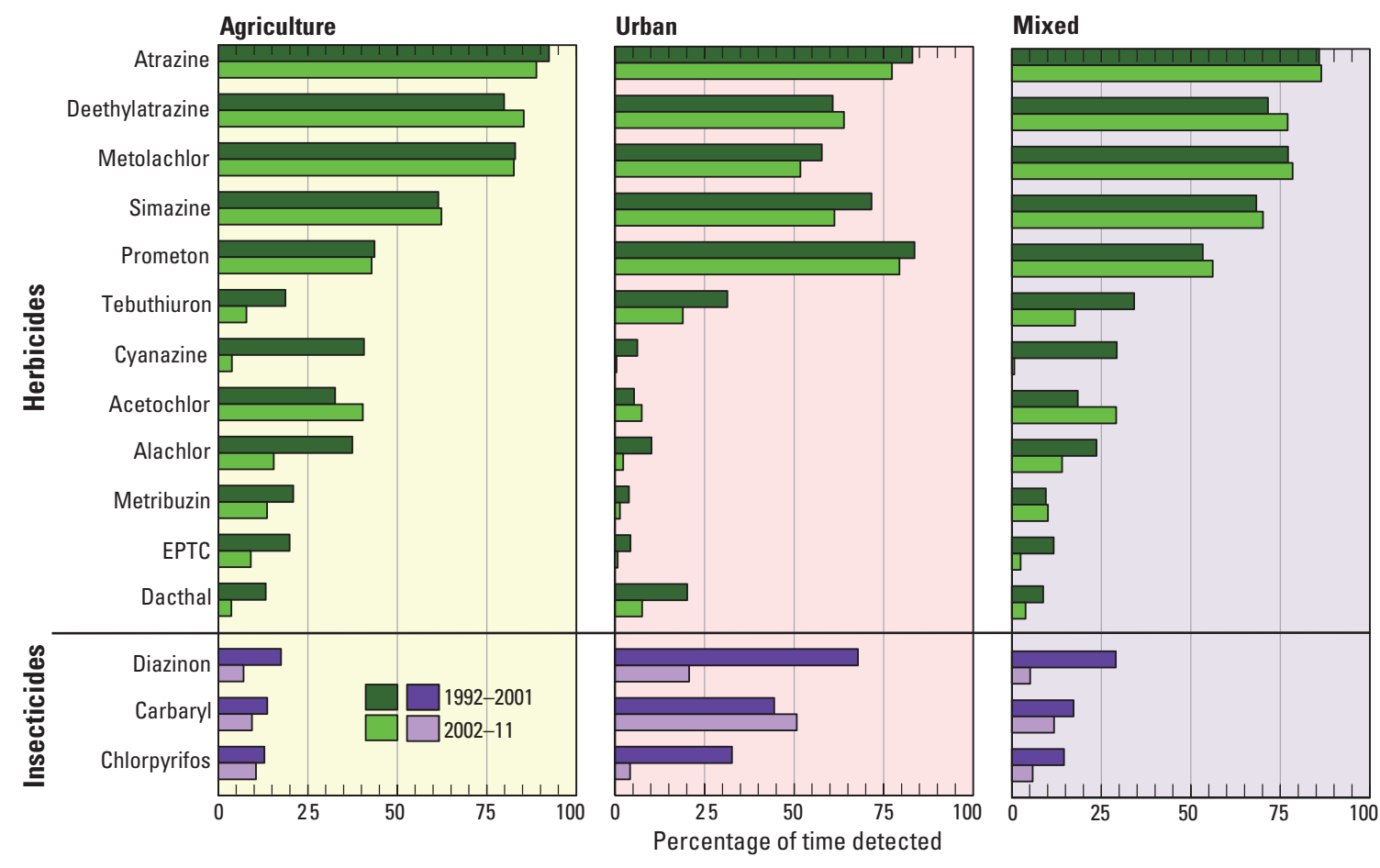

Pesticides measured only during 2002-11
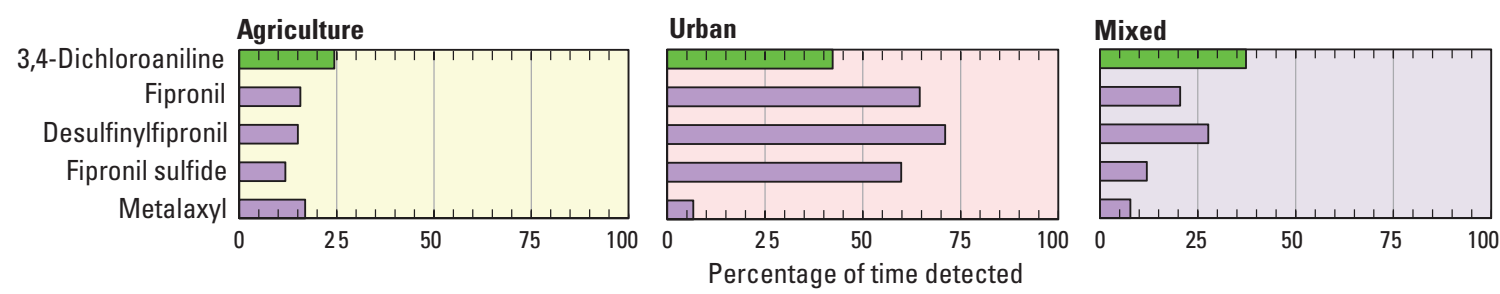

Figure 3. Percentage of time during a year that the most frequently detected pesticides were detected in streams and rivers in relation to land-use classification. 
The herbicides alachlor, cyanazine, EPTC, Dacthal, and tebuthiuron were detected less frequently in streams (more than 10 percent change) during the second decade than during the first decade. Sullivan and others (2009) found generally decreasing stream concentration trends for alachlor, cyanazine, and EPTC at individual stream sites within the Corn Belt. The decrease in the amount of time these pesticides were detected in streams between decades may reflect use changes from pesticide-registration cancellations and increased use of other herbicides. For example, cyanazine registration was voluntarily cancelled in the mid-1990s, which was followed by a rapid decline in cyanazine use. Alachlor use steadily declined after the introduction of acetochlor in the mid-1990s, which was an expected result following the registration of acetochlor (de Guzman and others, 2005). In addition, the introduction of genetically modified crops that are resistant to the herbicide, glyphosate, has seen rapid adoption over the course of the last two decades with a corresponding decrease in other herbicides over the same time period (fig. 1).

The organophosphate insecticides chlorpyrifos and diazinon were detected less frequently in streams (more than 10 percent change) during the second decade than during the first decade (fig. 3). Sullivan and others (2009) and Ryberg and others (2010) found generally decreasing stream concentration trends for these two pesticides at individual stream sites in agricultural and urban land-use areas, respectively. The change in detection frequency between the two decades for these pesticides reflects registration changes and changes in pesticide-use patterns. Various uses of chlorpyrifos and diazinon, primarily residential, began being voluntarily cancelled during the late-1990s, and these regulatory changes continued into the early-2000s. In addition, fipronil was first registered for use in the United States in 1996 (Jackson and others, 2009) and was suggested as an alternative to organophosphate insecticides for residential and commercial turf applications during the early2000s (U.S. Environmental Protection Agency, 2001).

Fipronil was detected in streams across all land-use classifications from 17 to 63 percent of the time during 2002-11 (fig. 3); however, fipronil was not included in the NAWQA and NASQAN efforts during 1992-2001 because it was not registered for use until 1996. Ryberg and others (2010) found a preponderance of increasing fipronil stream concentration trends for urban land-use streams from 2000 to 2008.

An important consideration when comparing detection frequencies over time is the possible impacts of analysis instrument changes. The assumption is that improvements in laboratory instrumentation could result in increased detection sensitivity over time. Alternatively, changes in instrumentation over time could possibly result in decreased sensitivity over time. Ryberg and others (2010) evaluated detections of trace concentrations in duplicate quality-control water samples collected from 1994 to 2005. They found that for most of the pesticides evaluated, improvements to instrumentation did not result in changes to detection sensitivities through time. However, instrumentation improvements did increase the detection sensitivity for tebuthiuron and carbaryl (Ryberg and others, 2010). As discussed previously, the amount of time tebuthiuron was detected in streams decreased from the first to the second decade (fig. 3); therefore, improvements to instrumentation was not a factor for this pesticide. For carbaryl, the differences in detection frequency between the first and second decades were less than 10 percent in all land-use classifications.

\section{Concentrations And Benchmark Comparisons}

Annual mean pesticide concentrations in streams were compared to HHBs to provide perspective; however, these comparisons are not appropriate for assessing compliance with drinking-water regulations, which are applied to treated water. The pesticide stream concentrations used in this report represent untreated water from sites that are not located at drinking-water intakes.

During 2002-11, one agriculture land-use stream had an annual mean pesticide concentration that exceeded an HHB (atrazine), and no urban or mixed land-use streams had annual mean pesticide concentrations that exceeded HHBs. In contrast, 17 percent of the agriculture land-use streams and 5 percent of mixed land-use streams exceeded HHBs during 1992-2001. During the previous decade, alpha-HCH (lindane), atrazine, cyanazine, molinate, dieldrin, and propargite annual mean concentrations exceeded HHBs in 10 agriculture and 4 mixed land-use streams. The differences in the percent of streams exceeding an HHB between the first and second decade are related to regulatory and use changes. Throughout the last three decades, various lindane uses were voluntarily cancelled by registrants; the last remaining uses were cancelled in 2006. Sullivan and others (2009) found downward trends in atrazine concentrations measured in agriculture streams of the Corn Belt. As mentioned previously, cyanazine registration was voluntarily cancelled in the mid-1990s, and cyanazine use sharply declined from the first to the second decade. During the early-2000s, molinate registration was voluntarily cancelled, and use sharply declined during 2002-11. Dieldrin registration was voluntarily cancelled during the late-1980s, and certain uses of propargite were voluntarily cancelled during the mid-1990s.

Pesticide concentrations in streams were compared to chronic ALBs. Acute ALBs were not used because the sampling frequencies do not adequately represent the highest concentrations that may be present in a stream during the year (Crawford, 2004). In addition, differences in sampling designs between the two decades limit comparisons between the decades based on the highest concentrations measured in streams. Specifically, sampling during the first decade included samples targeting high-flow events during the season when pesticides were expected to be transported to streams, 
while sampling during the second decade maintained a fixed-frequency sampling design. Therefore, comparison of the highest pesticide stream concentrations between the two decades would be biased.

During 2002-11, nearly two-thirds of agriculture land-use classification streams and nearly one-half of mixed land-use classification streams exceeded a chronic ALB (table 5). For urban land-use classification streams, 90 percent exceeded a chronic ALB. The insecticide fipronil exceeded chronic ALBs for more than 20 percent of the streams across all land-use classifications (fig. 4). The herbicide metolachlor (chronic ALB for $S$-metolachlor) exceeded chronic ALBs for more than 10 percent of agriculture and mixed land-use streams. Similarly, the insecticide malathion exceeded chronic ALBs for more than 10 percent of agriculture and urban land-use streams. The insecticides cis-permethrin (chronic ALB for permethrin) and dichlorvos exceeded chronic ALBs for more than 10 percent of mixed and urban land-use streams, respectively.

Overall, the percent of streams with pesticides that exceeded a chronic ALB was very similar between the two decades for the agriculture and mixed land-use groups (table 5). In terms of pesticides that were evaluated during both decades, the percent of urban land-use streams that exceeded a chronic ALB during the second decade was about the same as that for the first decade. However the inclusion of fipronil and dichlorvos during the second decade nearly doubled the percent of urban land-use streams that exceeded a chronic ALB during the second decade in comparison to the first decade (table 5; fig. 4).

During 2002-11, there were 21 pesticides that exceeded chronic ALBs compared to 16 that exceeded chronic ALBs during 1992-2001. Figure 4 shows a subset of the pesticides that had annual concentration statistics that exceeded a chronic ALB (pesticides and degradates that exceeded a chronic ALB for more than 5 percent of the stream sites, by pesticide and land-use classification). The second decade had a lower percent of streams exceeding a chronic ALB for the herbicide metolachlor than the first decade for all land-use classifications. For the agriculture land-use streams, this difference was greater than 10 percent. During the last part of the first decade

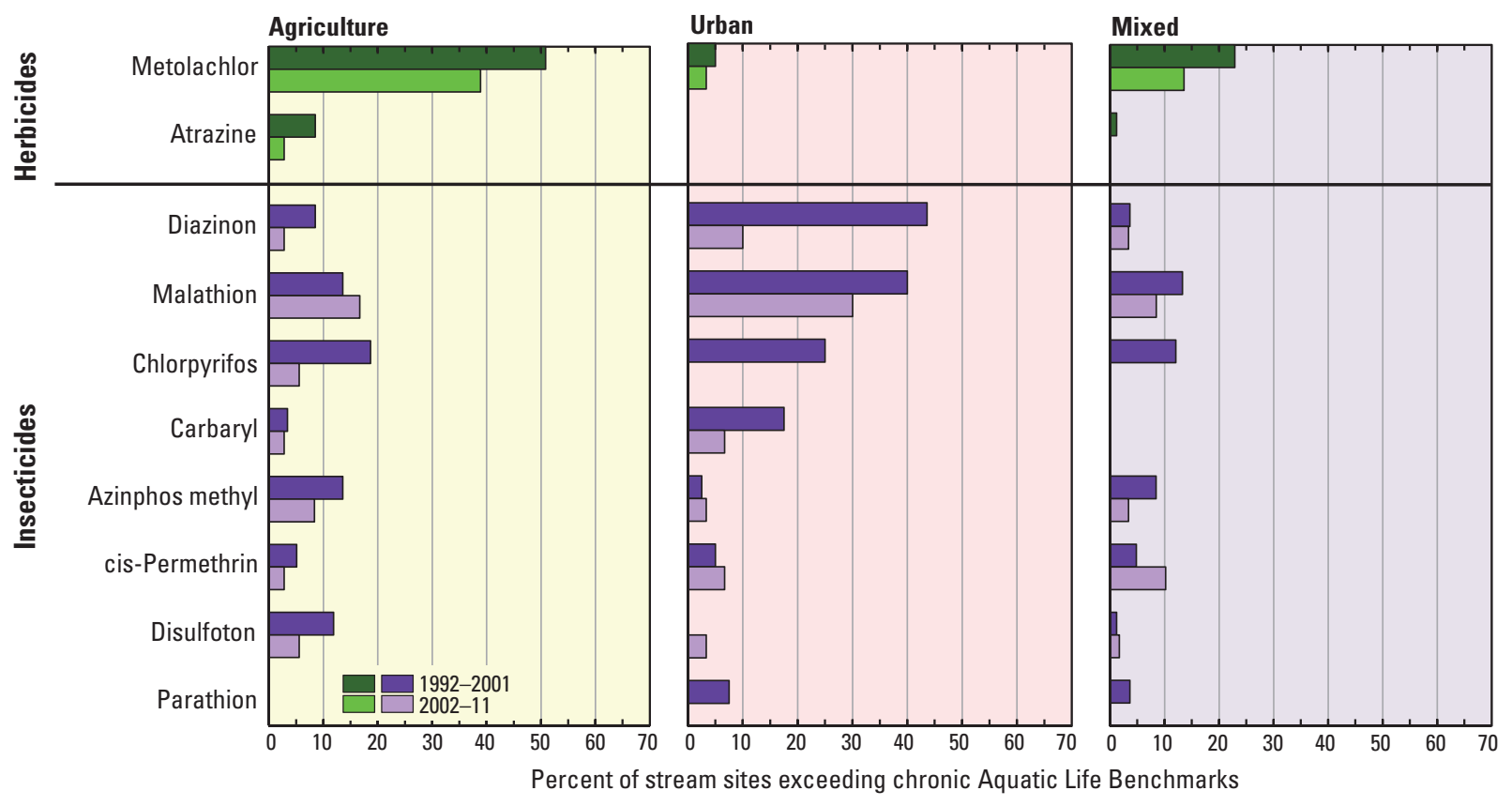

Pesticides measured only during 2002-11
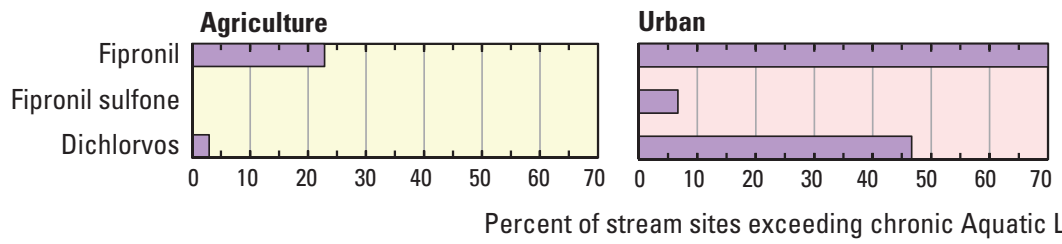

Mixed

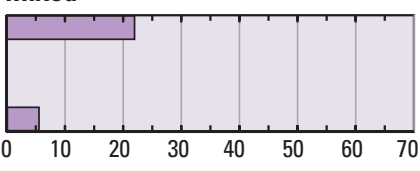

Figure 4. Pesticides that exceeded chronic Aquatic Life Benchmarks at more than 5 percent of stream sites and percent of streams by land-use classification. 
Table 5. Percent of streams with one or more pesticide concentration statistics that exceeded a chronic Aquatic Life Benchmark (ALB), by land-use classification.

\begin{tabular}{lcc}
\hline $\begin{array}{c}\text { Land-use } \\
\text { classification }\end{array}$ & $\begin{array}{c}\text { Percent of streams } \\
\text { exceeding } \\
\text { ALB 1992-2001 }\end{array}$ & $\begin{array}{c}\text { Percent of streams } \\
\text { exceeding } \\
\text { ALB 2002-11 }\end{array}$ \\
\hline Agriculture & 69 & 61 \\
Mixed & 45 & 46 \\
Urban & 53 & 90 \\
\hline
\end{tabular}

replaced by the resolved isomer $S$-metolachlor, which reduces the amount of pesticide required for the same agronomic effect (Hartzler, 2000). Although metolachlor was detected in streams for nearly the same amount of time for both decades (fig. 3), the decreased use (in terms of mass applied) because of the introduction of $S$-metolachlor likely contributed to the decrease in the percent of streams that exceeded a chronic ALB during 2002-11 when compared to 1992-2001.

For streams in the urban land-use classification group, the organophosphate insecticides chlorpyrifos, diazinon, and malathion, and the carbamate insecticide carbaryl all had decreases (greater than 10 percent) in the percent of streams exceeding a chronic ALB from the first decade to the second decade (fig. 4). This is consistent with the decreasing stream concentration trends found by Ryberg and others (2010) for chlorpyrifos and diazinon in individual urban land-use streams. These pesticides also were detected less frequently in streams during 1992-2001 compared to 2002-11 (fig. 3). In contrast, the percent of streams, across all land-use classifications, exceeding a chronic ALB for fipronil during the second decade was greater than all other insecticides during both decades. As discussed previously, fipronil registration and use began toward the end of the first decade and was a suggested alternative for organophosphate insecticides during the second decade.

\section{Summary}

This report provides an overview of U.S. Geological Survey National Water-Quality Assessment (NAWQA) and National Stream Quality Accounting Network (NASQAN) findings for pesticide occurrence (percent of time pesticides were detected) in U.S. streams during 2002-11 and compares them to findings during 1992-2001. In addition, pesticide stream concentrations are compared to Human Health Benchmark (HHBs) and chronic Aquatic Life Benchmark (ALBs) and differences between the decades discussed.

Direct and simple, one to one comparisons of pesticides in stream water between the two decades are not possible because of changes in stream sampling sites, sampling designs, and pesticides monitored within the programs over the last two decades. The comparisons in this report are from a site selection and land-use classification based on 2002-11 information that is applied to evaluate results for the 19922001 sites. In addition, the most current chronic ALBs are used in comparison to annual concentration statistics.

During 2002-11, atrazine, deethylatrazine (atrazine degradate), carbaryl, fipronil, fipronil sulfide (fipronil degradate), metolachlor, prometon, and simazine were detected more than 50 percent of the time in streams. One or more pesticides or pesticide degradates were detected more than 90 percent of the time in streams across all land uses during both decades. The overall amount of time pesticides were detected in streams was nearly the same between the first and second decades. However, there were differences between the two decades when comparing individual pesticides. The herbicides alachlor, cyanazine, EPTC, Dacthal, and tebuthiuron were detected less frequently in streams during 2002-11 than during 1992-2001. Regulatory changes and the increased use of acetochlor and glyphosate between the first decade and the second decade may be contributing to the decrease in the amount of time these pesticides were detected in streams. The organophosphate insecticides diazinon and chlorpyrifos were detected less frequently during 2002-11 than during 19922001. Product registration changes as well as the registration of the insecticide fipronil during the last part of the first decade may be contributing to the decrease in the amount of time these pesticides were detected in streams.

When stream concentration statistics were compared to HHBs, only one agriculture land-use stream had an annual mean pesticide concentration that exceeded an HHB (atrazine) during 2002-11. In contrast, during 1992-2001, about 17 percent of the agriculture land-use streams and one mixed landuse stream exceeded HHBs. The HHB exceedance difference between the first and second decades was the result of regulatory changes; specifically, cancellation of pesticide registration and subsequent decreased use.

During 2002-11, most agriculture and urban land-use classification streams and nearly one-half of mixed land-use classification streams had pesticide concentration statistics that exceeded a chronic ALB. The overall percent of streams that exceeded a chronic ALB was very similar between the two decades for agricultural and mixed land-use classification streams. However, for urban land-use classification streams the percent of streams exceeding a chronic ALB during 200211 nearly doubled that seen during 1992-2001. The inclusion of fipronil and dichlorvos monitoring during 2002-11 was the reason for this difference.

The summaries and comparisons between the two decades in this report were intended to be simple and descriptive overviews and not substitutes for more quantitative trend analysis that account for streamflow and other factors. Pesticide stream concentration trends at individual stream sites have been evaluated with more rigorous analysis methods for regions of the U.S. and selected time periods during these decades (Sullivan and others, 2009; Ryberg and others, 2010). Pesticide stream concentration trends using NAWQA and NASQAN results will continue to be evaluated in a series of studies involving quantitative site-based trend models. 


\section{References Cited}

Crawford, C.G., 2004, Sampling strategies for estimating acute and chronic exposures of pesticides in streams: Journal of the American Water Resources Association, v. 40, no. 2, p. 485-502, DOI:10.1111/j.1752-1688.2004.tb01045.x.

de Guzman, N.P., Hendley, P., Gustafson, D.I., van Wesenbeeck, I., Klein, A.J., Fuhrman, J.D., Travis, K., Simmons, N.D., Teskey, W.E., and Durham, R.B, 2005, The Acetochlor Registration Partnership state ground water monitoring program: Journal of Environmental Quality, v. 34, p. 793-803, doi:10.2134/jeq2003.0412.

Gilliom, R.J., Alley, W.M., and Gurtz, M.E., 1995, Design of the National Water-Quality Assessment ProgramOccurrence and distribution of water-quality conditions: U.S. Geological Survey Circular 1112, 33 p.

Gilliom, R.J., Barbash, J.E., Crawford, C.G., Hamilton, P.A., Martin, J.D., Nakagaki, Naomi, Nowell, L.H., Scott, J.C., Stackelberg, P.E., Thelin, G.P., and Wolock, D.M., 2006, The quality of our Nation's waters-Pesticides in the Nation's streams and ground water, 1992-2001: U.S. Geological Survey Circular 1291, 172 p.

Gilliom, R.J., and Helsel, D.R., 1986, Estimation of distributional parameters for censored trace level water quality data 1-Estimation techniques: Water Resources Research, v. 22, no. 2, p. 135-146, DOI:10.1029/WR022i002p00135.

Hartzler, Bob, 2000, Resolved isomers explained: Ames, Iowa, Iowa State University, Weed Science, accessed February 14, 2014, at http://www.weeds.iastate.edu/mgmt/qtr00-1/ isomers.htm.

Helsel, D.R., and Gilliom, R.J., 1986, Estimation of distributional parameters for censored trace level water quality data, 2-Verification and applications: Water Resources Research, v. 22, no. 2, p. 147-155, DOI:10.1029/ WR022i002p00147.

Hooper, R.P., Aulenbach, B.T., and Kelly, V.J., 2001, The National Stream Quality Accounting Network-A fluxbased approach to monitoring the water quality of large rivers: Hydrological Processes, v. 15, p. 1089-1106.

Jackson, D., Cornell, C.B., Luukinen, B., Buhl, K., and Stone, D., 2009, Fipronil Technical Fact Sheet: National Pesticide Information Center, Oregon State University Extension Services, accessed July 21, 2014, at http://npic.orst.edu/ factsheets/fiptech.pdf.

Larson, S.J., Crawford, C.G., and Gilliom, R.J., 2004, Development and application of Watershed Regressions for Pesticides (WARP) for estimating atrazine concentration distributions in streams: U.S. Geological Survey WaterResources Investigations Report 03-4047, 68 p.
Martin, J.D., 2009, Sources and preparation of data for assessing trends in concentrations of pesticides in streams of the United States, 1992-2006: U.S. Geological Survey Scientific Investigations Report 2009-5062, 41 p.

Norman, J.E., Kuivila, K.M., and Nowell, L.H., 2012, Prioritizing pesticide compounds for analytical methods development: U.S. Geological Survey Scientific Investigations Report 2012-5045, 206 p.

Ryberg, K.R., Vecchia, A.V., Martin, J.D., and Gilliom, R.J., 2010, Trends in pesticide concentrations in urban streams in the United States, 1992-2008: U.S. Geological Survey Scientific Investigations Report 2010-5139, 101 p.

Stone, W.W., 2013, Estimated annual agricultural pesticide use for counties of the conterminous United States, 1992-2009: U.S. Geological Survey Data Series 752, 1-p. pamphlet, 14 tables.

Stone, W.W., Crawford, C.G., and Gilliom, R.J, 2013, Watershed Regressions for Pesticides (WARP) models for predicting stream concentrations of multiple pesticides: Journal of Environmental Quality, v. 42, no. 6, p. 1838-1851, doi:10.2134/jeq2013.05.0179.

Stone, W.W., Gilliom, R.J., and Crawford, C.G., 2008, Watershed Regressions for Pesticides (WARP) for predicting annual maximum and maximum moving-average concentrations of atrazine in streams: U.S. Geological Survey OpenFile Report 2008-1186, 19 p.

Sullivan, D.J., Vecchia, A.V., Lorenz, D.L., Gilliom, R.J., and Martin, J.D., 2009, Trends in pesticide concentrations in corn-belt streams, 1996-2006: U.S. Geological Survey Scientific Investigations Report 2009-5132, 75 p.

Toccalino, P.L., Norman, J.E., and Schoephoester, K.M., 2014, Health-based screening levels for evaluating water-quality data: U.S. Geological Survey National Water-Quality Assessment Program, updated June 2014, accessed July 22, 2014, at http://water.usgs.gov/nawqa/HBSL.

U.S. Environmental Protection Agency, 2001, FY2001 conventional pesticides registration decisions, accessed February 14, 2014, at http://www.epa.gov/opprd001/workplan/ regdec2001.pdf.

U.S. Geological Survey, 2010, NASQAN National Stream Quality Accounting Network, 2001-2007 NASQAN design information, accessed September 15, 2011, at http://water. usgs.gov/nasqan/2001_2007_design_info.html. 



\section{Appendix 1.}

Table 1-1. Pesticide compounds used in the 1992-2001 and 2002-11 summaries......................14

Table 1-2. Stream sites used in the first decade (1992-2001) and second decade

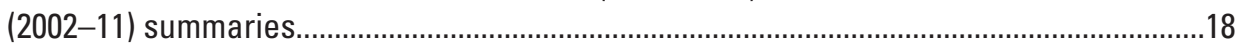


Table 1-1. Pesticide compounds used in the 1992-2001 and 2002-11 summaries.

[CASRN, Chemical Abstracts Service Registry Number ${ }^{\circledR} ;-$, not applicable]

\begin{tabular}{|c|c|c|c|c|c|}
\hline $\begin{array}{l}\text { Pesticide compound } \\
\text { (synonym) }\end{array}$ & $\begin{array}{l}\text { Type of pesticide compound } \\
\text { (parent pesticide, if degradate) }\end{array}$ & CASRN ${ }^{1}$ & $\begin{array}{l}\text { Parameter } \\
\text { code }\end{array}$ & $\begin{array}{c}1992- \\
2001 \\
\end{array}$ & 2002-11 \\
\hline Acetochlor & Herbicide & $34256-82-1$ & 49260 & Yes & Yes \\
\hline Alachlor & Herbicide & $15972-60-8$ & 46342 & Yes & Yes \\
\hline 2,6-Diethylaniline & Degradate (Alachlor) & $579-66-8$ & 82660 & Yes & Yes \\
\hline 2-Chloro-2,6-diethylacetanilide & Degradate (Alachlor) & $6967-29-9$ & 61618 & & Yes \\
\hline alpha-Endosulfan & Insecticide & $959-98-8$ & 34362 & & Yes \\
\hline Endosulfan ether & Degradate (alpha-Endosulfan) & $3369-52-6$ & 61642 & & Yes \\
\hline Endosulfan sulfate & $\begin{array}{l}\text { Degradate (alpha-Endosulfan, } \\
\text { beta-Endosulfan) }\end{array}$ & $1031-07-8$ & 61590 & & Yes \\
\hline Atrazine & Herbicide & $1912-24-9$ & 39632 & Yes & Yes \\
\hline Deethylatrazine & Degradate (Atrazine) & $6190-65-4$ & 04040 & Yes & Yes \\
\hline Azinphos-methyl (Guthion) & Insecticide & $86-50-0$ & 82686 & Yes & Yes \\
\hline Azinphos-methyl-oxon & Degradate (Azinphos-methyl) & $961-22-8$ & 61635 & & Yes \\
\hline Benfluralin & Herbicide & $1861-40-1$ & 82673 & Yes & Yes \\
\hline 2-Amino-N-isopropylbenzamide & Degradate (Bentazon) & $30391-89-0$ & 61617 & & Yes \\
\hline beta-Endosulfan & Insecticide & $33213-65-9$ & 34357 & & Yes \\
\hline Bifenthrin & Insecticide & $82657-04-3$ & 61580 & & Yes \\
\hline Butylate & Herbicide & $2008-41-5$ & 04028 & Yes & Yes \\
\hline Carbaryl & Insecticide & $63-25-2$ & 82680 & Yes & Yes \\
\hline 1-Naphthol & Degradate (Carbaryl, Napromide) & $90-15-3$ & 49295 & & Yes \\
\hline Carbofuran & Insecticide & $1563-66-2$ & 82674 & Yes & Yes \\
\hline 2,5-Dichloroaniline & Degradate (Chloramben) & $95-82-9$ & 61614 & & Yes \\
\hline Chlorpyrifos & Insecticide & $2921-88-2$ & 38933 & Yes & Yes \\
\hline Chlorpyrifos_oxon & Degradate (Chlorpyrifos) & $5598-15-2$ & 61636 & & Yes \\
\hline cis-Permethrin & Insecticide & $61949-76-6$ & 82687 & Yes & Yes \\
\hline cis-Propiconazole & Fungicide & $112721-87-6$ & 79846 & & Yes \\
\hline Cyanazine & Herbicide & $21725-46-2$ & 04041 & Yes & Yes \\
\hline Cycloate & Herbicide & $1134-23-2$ & 04031 & & Yes \\
\hline Cyfluthrin & Insecticide & $68359-37-5$ & 61585 & & Yes \\
\hline $\begin{array}{l}\text { cis-Methyl-3-(2,2-dichlorovinyl)- } \\
\text { 2,2-dimethyl-(1-cyclopropane)- } \\
\text { carboxylate }\end{array}$ & Degradate (Cyfluthrin) & $59897-93-7$ & 79842 & & Yes \\
\hline $\begin{array}{l}\text { trans-Methyl-3-(2,2-dichlorovinyl)- } \\
\text { 2,2-dimethyl-(1-cyclopropane)- } \\
\text { carboxylate }\end{array}$ & Degradate (Cyfluthrin) & $59897-94-8$ & 79843 & & Yes \\
\hline Cypermethrin & Insecticide & $52315-07-8$ & 61586 & & Yes \\
\hline Dacthal (DCPA) & Herbicide & $1861-32-1$ & 82682 & Yes & Yes \\
\hline Diazinon & Insecticide & $333-41-5$ & 39572 & Yes & Yes \\
\hline Diazoxon & Degradate (Diazinon) & $962-58-3$ & 61638 & & Yes \\
\hline Dichlorvos & $\begin{array}{l}\text { Insecticide/Fumigant/Degradate } \\
\text { (Naled) }\end{array}$ & $62-73-7$ & 38775 & & Yes \\
\hline Dicrotophos & Insecticide & $141-66-2$ & 38454 & & Yes \\
\hline
\end{tabular}


Table 1-1. Pesticide compounds used in the 1992-2001 and 2002-11 summaries.-Continued

[CASRN, Chemical Abstracts Service Registry Number®;- , not applicable]

\begin{tabular}{|c|c|c|c|c|c|}
\hline $\begin{array}{l}\text { Pesticide compound } \\
\text { (synonym) }\end{array}$ & $\begin{array}{l}\text { Type of pesticide compound } \\
\text { (parent pesticide, if degradate) }\end{array}$ & CASRN ${ }^{1}$ & $\begin{array}{l}\text { Parameter } \\
\text { code }\end{array}$ & $\begin{array}{c}1992- \\
2001\end{array}$ & 2002-11 \\
\hline Dieldrin & Insecticide & $60-57-1$ & 39381 & Yes & Yes \\
\hline Dimethoate & Insecticide & $60-51-5$ & 82662 & & Yes \\
\hline Disulfoton & Insecticide & $298-04-4$ & 82677 & Yes & Yes \\
\hline Disulfoton_sulfone & Degradate (Disulfoton) & $2497-06-5$ & 61640 & & Yes \\
\hline Disulfoton_sulfoxide & Degradate (Disulfoton) & $2497-07-6$ & 61641 & & Yes \\
\hline E-Dimethomorph & Fungicide & - & 79844 & & Yes \\
\hline 3,4-Dichloroaniline & Degradate (Diuron) & $95-76-1$ & 61625 & & Yes \\
\hline EPTC & Herbicide & $759-94-4$ & 82668 & Yes & Yes \\
\hline Ethalfluralin & Herbicide & $55283-68-6$ & 82663 & Yes & Yes \\
\hline Ethion & Insecticide & $563-12-2$ & 82346 & & Yes \\
\hline Ethion_monoxon & Degradate (Ethion) & $17356-42-2$ & 61644 & & Yes \\
\hline Ethoprophos (Ethoprop) & Insecticide & $13194-48-4$ & 82672 & Yes & Yes \\
\hline $\begin{array}{l}\text { O-Ethyl-O-methyl-S-propylphospho- } \\
\text { rothioate }\end{array}$ & Degradate (Ethoprophos) & $76960-87-7$ & 61660 & & Yes \\
\hline Fenamiphos & Nematocide & $22224-92-6$ & 61591 & & Yes \\
\hline Fenamiphos_sulfone & Degradate (Fenamiphos) & $31972-44-8$ & 61645 & & Yes \\
\hline Fenamiphos_sulfoxide & Degradate (Fenamiphos) & $31972-43-7$ & 61646 & & Yes \\
\hline Fenthion & Insecticide & $55-38-9$ & 38801 & & Yes \\
\hline Fenthion_sulfoxide & Degradate (Fenthion) & $3761-41-9$ & 61647 & & Yes \\
\hline Fipronil & Insecticide & $120068-37-3$ & 62166 & & Yes \\
\hline Desulfinylfipronil & Degradate (Fipronil) & - & 62170 & & Yes \\
\hline Desulfinylfipronil_amide & Degradate (Fipronil) & - & 62169 & & Yes \\
\hline Fipronil_sulfide & Degradate (Fipronil) & $120067-83-6$ & 62167 & & Yes \\
\hline Fipronil_sulfone & Degradate (Fipronil) & $120068-36-2$ & 62168 & & Yes \\
\hline Flumetralin & Plant_Growth_Regulator & $62924-70-3$ & 61592 & & Yes \\
\hline 3-(Trifluoromethyl)aniline & Degradate (Fluometuron) & $98-16-8$ & 61630 & & Yes \\
\hline Fonofos & Insecticide & $944-22-9$ & 04095 & Yes & Yes \\
\hline gamma-HCH (Lindane) & Insecticide & $58-89-9$ & 39341 & Yes & Yes \\
\hline alpha-HCH & Degradate (gamma-HCH) & $319-84-6$ & 34253 & Yes & Yes \\
\hline Hexazinone & Herbicide & $51235-04-2$ & 04025 & & Yes \\
\hline Iprodione & Fungicide & $36734-19-7$ & 61593 & & Yes \\
\hline 3,5-Dichloroaniline & Degradate (Iprodione) & $626-43-7$ & 61627 & & Yes \\
\hline Isofenphos & Insecticide & $25311-71-1$ & 61594 & & Yes \\
\hline lambda-Cyhalothrin & Insecticide & $91465-08-6$ & 61595 & & Yes \\
\hline Linuron & Herbicide & $330-55-2$ & 82666 & Yes & Yes \\
\hline Malathion & Insecticide & $121-75-5$ & 39532 & Yes & Yes \\
\hline Malaoxon & Degradate (Malathion) & $1634-78-2$ & 61652 & & Yes \\
\hline Metalaxyl & Fungicide & $57837-19-1$ & 61596 & & Yes \\
\hline 4-Chloro-2-methylphenol & Degradate (MCPA) & $1570-64-5$ & 61633 & & Yes \\
\hline Methidathion & Insecticide & $950-37-8$ & 61598 & & Yes \\
\hline
\end{tabular}


Table 1-1. Pesticide compounds used in the 1992-2001 and 2002-11 summaries.-Continued

[CASRN, Chemical Abstracts Service Registry Number®;-—, not applicable]

\begin{tabular}{|c|c|c|c|c|c|}
\hline $\begin{array}{l}\text { Pesticide compound } \\
\text { (synonym) }\end{array}$ & $\begin{array}{l}\text { Type of pesticide compound } \\
\text { (parent pesticide, if degradate) }\end{array}$ & CASRN ${ }^{1}$ & $\begin{array}{l}\text { Parameter } \\
\text { code }\end{array}$ & $\begin{array}{l}1992- \\
2001\end{array}$ & 2002-11 \\
\hline Metolachlor & Herbicide & $51218-45-2$ & 39415 & Yes & Yes \\
\hline 2-Ethyl-6-methylaniline & Degradate (Metolaclor) & $24549-06-2$ & 61620 & & Yes \\
\hline Metribuzin & Herbicide & 21087-64-9 & 82630 & Yes & Yes \\
\hline Molinate & Herbicide & $2212-67-1$ & 82671 & Yes & Yes \\
\hline Myclobutanil & Fungicide & 88671-89-0 & 61599 & & Yes \\
\hline Napropamide & Herbicide & $15299-99-7$ & 82684 & Yes & Yes \\
\hline 1,4-Napthaquinone & Degradate (Napromide) & $130-15-4$ & 61611 & & Yes \\
\hline Oxyfluorfen & Herbicide & $42874-03-3$ & 61600 & & Yes \\
\hline p,p'-DDE & Degradate (DDT) & $72-55-9$ & 34653 & Yes & Yes \\
\hline 4,4'-Dichlorobenzophenone & Degradate (DDT, Dicofol) & $90-98-2$ & 61631 & & Yes \\
\hline Paraoxon-ethyl & Insecticide/Degradate (Parathion) & $311-45-5$ & 61663 & & Yes \\
\hline Parathion (Ethyl parathion) & Insecticide & $56-38-2$ & 39542 & Yes & Yes \\
\hline Parathion-methyl (Methyl parathion) & Insecticide & $298-00-0$ & 82667 & Yes & Yes \\
\hline Paraoxon-methyl & Degradate (Methyl parathion) & $950-35-6$ & 61664 & & Yes \\
\hline Pebulate & Herbicide & $1114-71-2$ & 82669 & Yes & Yes \\
\hline Pendimethalin & Herbicide & $40487-42-1$ & 82683 & Yes & Yes \\
\hline Phorate & Insecticide & $298-02-2$ & 82664 & Yes & Yes \\
\hline Phorate_oxon & Degradate (Phorate) & $2600-69-3$ & 61666 & & Yes \\
\hline Phosmet & Insecticide & $732-11-6$ & 61601 & & Yes \\
\hline Phosmet_oxon & Degradate (Phosmet) & $3735-33-9$ & 61668 & & Yes \\
\hline Profenofos & Insecticide & $41198-08-7$ & 61603 & & Yes \\
\hline Prometon & Herbicide & $1610-18-0$ & 04037 & Yes & Yes \\
\hline Prometryn & Herbicide & $7287-19-6$ & 04036 & & Yes \\
\hline Propachlor & Herbicide & $1918-16-7$ & 04024 & Yes & Yes \\
\hline Propanil & Herbicide & $709-98-8$ & 82679 & Yes & Yes \\
\hline Propargite & Acaricide & $2312-35-8$ & 82685 & Yes & Yes \\
\hline 2-(4-tert-butylphenoxy)-cyclohexanol & Degradate (Propargite) & $1942-71-8$ & 61637 & & Yes \\
\hline Propetamphos & Insecticide & $31218-83-4$ & 61604 & & Yes \\
\hline Propyzamide (Pronamide) & Herbicide & $23950-58-5$ & 82676 & Yes & Yes \\
\hline Simazine & Herbicide & $122-34-9$ & 04035 & Yes & Yes \\
\hline Sulfotepp & Insecticide & $3689-24-5$ & 61605 & & Yes \\
\hline Sulprofos & Insecticide & $35400-43-2$ & 38716 & & Yes \\
\hline Tebuconazole & Fungicide & $107534-96-3$ & 62852 & & Yes \\
\hline Tebupirimfos & Insecticide & $96182-53-5$ & 61602 & & Yes \\
\hline Tebupirimfos_oxon & Degradate (Tebupirimfos) & - & 61669 & & Yes \\
\hline Tebuthiuron & Herbicide & $34014-18-1$ & 82670 & Yes & Yes \\
\hline Tefluthrin & Insecticide & $79538-32-2$ & 61606 & & Yes \\
\hline Temephos & Insecticide & $3383-96-8$ & 61607 & & Yes \\
\hline Terbacil & Herbicide & $5902-51-2$ & 82665 & Yes & Yes \\
\hline
\end{tabular}


Table 1-1. Pesticide compounds used in the 1992-2001 and 2002-11 summaries.-Continued

[CASRN, Chemical Abstracts Service Registry Number®;-, not applicable]

\begin{tabular}{|c|c|c|c|c|c|}
\hline $\begin{array}{l}\text { Pesticide compound } \\
\text { (synonym) }\end{array}$ & $\begin{array}{l}\text { Type of pesticide compound } \\
\text { (parent pesticide, if degradate) }\end{array}$ & CASRN $^{1}$ & $\begin{array}{l}\text { Parameter } \\
\text { code }\end{array}$ & $\begin{array}{c}1992- \\
2001\end{array}$ & 2002-11 \\
\hline Terbufos & Insecticide & $13071-79-9$ & 82675 & Yes & Yes \\
\hline Terbufos_sulfone_oxygen_analog & Degradate (Terbufos) & $56070-15-6$ & 61674 & & Yes \\
\hline Terbuthylazine & Herbicide & $5915-41-3$ & 04022 & & Yes \\
\hline Thiobencarb & Herbicide & $28249-77-6$ & 82681 & Yes & Yes \\
\hline 4-Chlorobenzylmethyl_sulfone & Degradate (Thiobencarb) & $98-57-7$ & 61634 & & Yes \\
\hline trans-Propiconazole & Fungicide & $120523-07-1$ & 79847 & & Yes \\
\hline Triallate & Herbicide & $2303-17-5$ & 82678 & Yes & Yes \\
\hline Tribuphos & Defoliant & $78-48-8$ & 61610 & & Yes \\
\hline Trifluralin & Herbicide & $1582-09-8$ & 82661 & Yes & Yes \\
\hline Z-Dimethomorph & Fungicide & - & 79845 & & Yes \\
\hline
\end{tabular}

${ }^{1}$ This report contains CAS Registry Numbers ${ }^{\circledR}$, which is a Registered Trademark of the American Chemical Society. CAS recommends the verification of the CASRNs through CAS Client Services ${ }^{\mathrm{SM}}$. 
Table 1-2. Stream sites used in the first decade (1992-2001) and second decade (2002-11) summaries.

$\left[\mathrm{km}^{2}\right.$, square kilometer; Cr, Creek; Ri, River; Irr Dist; Irrigation District; No., number; MA, Massachusetts; CT, Connecticut; NY, New York; NJ, New Jersey; PA, Pennsylvania; MD, Maryland; VA, Virginia; WV, West Virginia; DC, District of Columbia; NC, North Carolina; SC, South Carolina; GA, Georgia; FL, Florida; AL, Alabama; OH, Ohio; IN, Indiana; TN, Tennessee; KY, Kentucky; IL, Illinois; WI, Wisconsin; MI, Michigan; MN, Minnesota; ND, North Dakota; IA, Iowa; MT, Montana; WY, Wyoming; CO, Colorado; NE, Nebraska; MO, Missouri; AR, Arkansas; MS, Mississippi; LA, Louisiana; TX, Texas; AZ, Arizona; VT, Vermont; NV, Nevada; CA, California; WA, Washington; ID, Idaho; OR, Oregon]

\begin{tabular}{|c|c|c|c|c|c|}
\hline \multirow{2}{*}{ Site number } & \multirow{2}{*}{ Site name } & \multirow{2}{*}{$\begin{array}{l}\text { Watershed area } \\
\qquad\left(\mathbf{k m}^{2}\right)\end{array}$} & \multirow{2}{*}{ Land use } & \multicolumn{2}{|c|}{ Number of years } \\
\hline & & & & $\begin{array}{c}1992- \\
2001\end{array}$ & 2002-11 \\
\hline 01102500 & Aberjona River at Winchester, MA & 60 & Urban & 2 & \\
\hline 01104615 & Charles River near Watertown, MA & 695 & Urban & & 2 \\
\hline 01184000 & Connecticut River at Thompsonville, CT & 25,000 & Mixed & 4 & 3 \\
\hline 01209710 & Norwalk River at Winnipauk, CT & 85 & Urban & 5 & 3 \\
\hline 01349150 & Canajoharie Creek near Canajoharie, NY & 155 & Agriculture & 5 & 3 \\
\hline 01356190 & Lisha Kill northwest of Niskayuna, NY & 40 & Urban & 1 & 3 \\
\hline 01357500 & Mohawk River at Cohoes, NY & 9,110 & Mixed & 8 & 2 \\
\hline 01403300 & Raritan River at Bound Brook, NJ & 2,070 & Urban & 3 & 6 \\
\hline 01403900 & Bound Brook at Middlesex, NJ & 126 & Urban & 2 & 2 \\
\hline 01410784 & Great Egg Harbor River near Sicklerville, NJ & 39 & Urban & 2 & \\
\hline 01454700 & Lehigh River at Easton, PA & 3,520 & Mixed & 1 & \\
\hline 01463500 & Delaware River at Trenton, NJ & 17,600 & Mixed & 2 & 2 \\
\hline 01464907 & Little Neshaminy Creek near Warminster, PA & 72 & Urban & 2 & 1 \\
\hline 01470779 & Tulpehocken Creek near Bernville, PA & 179 & Mixed & 2 & \\
\hline 01472157 & French Creek near Phoenixville, PA & 152 & Mixed & & 1 \\
\hline 01474500 & Schuylkill River at Philadelphia, PA & 4,900 & Mixed & 2 & \\
\hline 01485000 & Pocomoke River at Willards, MD & 138 & Mixed & 1 & \\
\hline 01493112 & Chesterville Branch near Crumpton, MD & 17 & Agriculture & 1 & \\
\hline 01493500 & Morgan Creek near Kennedyville, MD & 33 & Agriculture & & 3 \\
\hline 01555400 & East Mahantango Creek at Klingerstown, PA & 116 & Agriculture & 2 & \\
\hline 01571490 & Cedar Run at Eberlys Mill, PA & 33 & Urban & 3 & \\
\hline 01573095 & Bachman Run at Annville, PA & 20 & Mixed & 1 & \\
\hline 01576540 & Mill Creek near Lyndon, PA & 141 & Mixed & 2 & \\
\hline 01578310 & Susquehanna River at Conowingo, MD & 70,100 & Mixed & 2 & 6 \\
\hline 01621050 & Muddy Creek at Mount Clinton, VA & 37 & Agriculture & 2 & 3 \\
\hline 01636500 & Shenandoah River at Millville, WV & 7,880 & Mixed & 1 & \\
\hline 01639000 & Monocacy River at Bridgeport, MD & 449 & Mixed & 1 & \\
\hline 01646580 & Potomac River at Washington, DC & 30,000 & Mixed & 4 & 7 \\
\hline 01654000 & Accotink Creek near Annandale, VA & 61 & Urban & 2 & 4 \\
\hline 02082731 & Devils Cradle Creek near Alert, NC & 35 & Mixed & 1 & \\
\hline 02083500 & Tar River at Tarboro, NC & 5,750 & Mixed & 1 & \\
\hline 02083833 & Pete Mitchell Swamp near Penny Hill, NC & 45 & Agriculture & 1 & \\
\hline 02084160 & Chicod Cr near Simpson, NC & 109 & Mixed & 1 & 1 \\
\hline 02084558 & Albemarle Canal near Swindell, NC & 191 & Agriculture & 1 & \\
\hline 02087580 & Swift Creek near Apex, NC & 54 & Urban & & 5 \\
\hline 02089500 & Neuse River at Kinston, NC & 7,020 & Mixed & 4 & 7 \\
\hline
\end{tabular}


Table 1-2. Stream sites used in the first decade (1992-2001) and second decade (2002-11) summaries.-Continued

$\left[\mathrm{km}^{2}\right.$, square kilometer; Cr, Creek; Ri, River; Irr Dist; Irrigation District; No., number; MA, Massachusetts; CT, Connecticut; NY, New York; NJ, New Jersey; PA, Pennsylvania; MD, Maryland; VA, Virginia; WV, West Virginia; DC, District of Columbia; NC, North Carolina; SC, South Carolina; GA, Georgia; FL, Florida; AL, Alabama; OH, Ohio; IN, Indiana; TN, Tennessee; KY, Kentucky; IL, Illinois; WI, Wisconsin; MI, Michigan; MN, Minnesota; ND, North Dakota; IA, Iowa; MT, Montana; WY, Wyoming; CO, Colorado; NE, Nebraska; MO, Missouri; AR, Arkansas; MS, Mississippi; LA, Louisiana; TX, Texas; AZ, Arizona; VT, Vermont; NV, Nevada; CA, California; WA, Washington; ID, Idaho; OR, Oregon]

\begin{tabular}{|c|c|c|c|c|c|}
\hline \multirow{2}{*}{ Site number } & \multirow{2}{*}{ Site name } & \multirow{2}{*}{$\begin{array}{c}\text { Watershed area } \\
\qquad\left(\mathbf{k m}^{2}\right)\end{array}$} & \multirow{2}{*}{ Land use } & \multicolumn{2}{|c|}{ Number of years } \\
\hline & & & & $\begin{array}{c}1992- \\
2001 \\
\end{array}$ & 2002-11 \\
\hline 02091500 & Contentnea Creek at Hookerton, NC & 1,910 & Agriculture & 3 & 3 \\
\hline 02169570 & Gills Creek at Columbia, SC & 154 & Urban & 1 & 2 \\
\hline 02174250 & Cow Castle Creek near Bowman, SC & 62 & Mixed & 2 & 2 \\
\hline 02175000 & Edisto River near Givhans, SC & 7,080 & Mixed & 4 & 3 \\
\hline 02215100 & Tucsawhatchee Creek near Hawkinsville, GA & 420 & Mixed & 1 & \\
\hline 02226160 & Altamaha River near Everett City, GA & 36,100 & Mixed & & 4 \\
\hline 02281200 & Hillsboro Canal near Shawano, FL & 806 & Agriculture & 3 & 1 \\
\hline 02289034 & U.S. Sugar Outflow Canal near Clewiston, FL & 73 & Agriculture & 1 & \\
\hline 02306774 & Rocky Creek near Citrus Park, FL & 46 & Urban & & 2 \\
\hline 02317797 & Little River near Tifton, GA & 335 & Mixed & 1 & 1 \\
\hline 02318500 & Withlacoochee River near Quitman, GA & 3,860 & Mixed & 3 & 3 \\
\hline 02326838 & Lafayette Creek near Tallahassee, FL & 25 & Urban & 2 & \\
\hline 02335870 & Sope Creek near Marietta, GA & 80 & Urban & 2 & 4 \\
\hline 02336300 & Peachtree Creek at Atlanta, GA & 222 & Urban & 1 & \\
\hline 02338000 & Chattahoochee River near Whitesburg, GA & 6,250 & Urban & 3 & 7 \\
\hline 02350080 & Lime Creek near Cobb, GA & 162 & Mixed & 2 & 4 \\
\hline 02356980 & Aycocks Creek near Boykin, GA & 271 & Mixed & 1 & \\
\hline 02359170 & Apalachicola River near Sumatra, FL & 49,800 & Mixed & & 1 \\
\hline 02424000 & Cahaba River at Centreville, $\mathrm{AL}$ & 2660 & Mixed & 2 & 1 \\
\hline 02429500 & Alabama River at Claiborne, $\mathrm{AL}$ & 56,900 & Mixed & 1 & 3 \\
\hline 02444490 & Bogue Chitto near Memphis, AL & 136 & Agriculture & 1 & \\
\hline 02469762 & Tombigbee River near Coffeeville, AL & 47,800 & Mixed & & 1 \\
\hline 02470500 & Mobile River at Mt. Vernon, AL & 111,400 & Mixed & & 4 \\
\hline 03049625 & Allegheny River at New Kensington, PA & 29,700 & Mixed & 1 & \\
\hline 03049646 & Deer Creek near Dorseyville, PA & 70 & Urban & 1 & \\
\hline 03167000 & Reed Creek at Grahams Forge, VA & 669 & Mixed & 1 & \\
\hline 03176500 & New River at Glen Lyn, VA & 9,780 & Mixed & 1 & \\
\hline 03201300 & Kanawha River at Winfield, WV & 30,600 & Mixed & 1 & \\
\hline 03267900 & Mad River near Eagle City, OH & 802 & Agriculture & 3 & 3 \\
\hline 03274000 & Great Miami River at Hamilton, $\mathrm{OH}$ & 9,400 & Mixed & 2 & \\
\hline 03303280 & Ohio River at Cannelton Dam at Cannelton, IN & 251,200 & Mixed & 6 & 10 \\
\hline 03353637 & Little Buck Creek near Indianapolis, IN & 45 & Urban & 3 & 2 \\
\hline 03357330 & Big Walnut Creek near Roachdale, IN & 339 & Agriculture & & 2 \\
\hline 03360895 & Kessinger Ditch near Monroe City, IN & 146 & Agriculture & 1 & \\
\hline 03374100 & White River at Hazleton, IN & 29,300 & Mixed & 10 & 7 \\
\hline 03378500 & Wabash River at New Harmony, IN & 75,700 & Agriculture & 5 & 10 \\
\hline
\end{tabular}


Table 1-2. Stream sites used in the first decade (1992-2001) and second decade (2002-11) summaries.-Continued

$\left[\mathrm{km}^{2}\right.$, square kilometer; Cr, Creek; Ri, River; Irr Dist; Irrigation District; No., number; MA, Massachusetts; CT, Connecticut; NY, New York; NJ, New Jersey; PA, Pennsylvania; MD, Maryland; VA, Virginia; WV, West Virginia; DC, District of Columbia; NC, North Carolina; SC, South Carolina; GA, Georgia; FL, Florida; AL, Alabama; OH, Ohio; IN, Indiana; TN, Tennessee; KY, Kentucky; IL, Illinois; WI, Wisconsin; MI, Michigan; MN, Minnesota; ND, North Dakota; IA, Iowa; MT, Montana; WY, Wyoming; CO, Colorado; NE, Nebraska; MO, Missouri; AR, Arkansas; MS, Mississippi; LA, Louisiana; TX, Texas; AZ, Arizona; VT, Vermont; NV, Nevada; CA, California; WA, Washington; ID, Idaho; OR, Oregon]

\begin{tabular}{|c|c|c|c|c|c|}
\hline \multirow{2}{*}{ Site number } & \multirow{2}{*}{ Site name } & \multirow{2}{*}{$\begin{array}{l}\text { Watershed area } \\
\left(\mathbf{k m}^{2}\right)\end{array}$} & \multirow{2}{*}{ Land use } & \multicolumn{2}{|c|}{ Number of years } \\
\hline & & & & $\begin{array}{c}1992- \\
2001\end{array}$ & 2002-11 \\
\hline 03455000 & French Broad River near Newport, TN & 4,800 & Mixed & 1 & \\
\hline 03466208 & Big Limestone Creek near Limestone, TN & 205 & Agriculture & 2 & 1 \\
\hline 03467609 & Nolichucky River near Lowland, TN & 4,370 & Mixed & 2 & 1 \\
\hline 03526000 & Copper Creek near Gate City, VA & 277 & Mixed & 1 & \\
\hline 03528000 & Clinch River above Tazewell, TN & 3,820 & Mixed & 1 & \\
\hline 03575100 & Flint River near Brownsboro, AL & 969 & Agriculture & 3 & 2 \\
\hline 03609750 & $\begin{array}{l}\text { Tennessee River at Highway } 60 \text { near Paducah, } \\
\text { KY }\end{array}$ & 104,500 & Mixed & 5 & 4 \\
\hline 03612500 & Ohio River at Dam 53 near Grand Chain, IL & 526,000 & Mixed & 6 & 10 \\
\hline 04072050 & Duck Creek near Howard, WI & 247 & Agriculture & 3 & 3 \\
\hline 04087000 & Milwaukee River at Milwaukee, WI & 1,810 & Mixed & 3 & 2 \\
\hline 04159492 & Black River near Jeddo, MI & 1,200 & Agriculture & 1 & \\
\hline 04161820 & Clinton River at Sterling Heights, MI & 803 & Urban & 1 & 2 \\
\hline 04175600 & River Raisin near Manchester, MI & 331 & Mixed & & 1 \\
\hline 04178000 & St. Joseph River near Newville, IN & 1,600 & Agriculture & 2 & \\
\hline 04183000 & Maumee River at New Haven, IN & 5,040 & Mixed & 1 & \\
\hline 04186500 & Auglaize River near Fort Jennings, OH & 858 & Agriculture & 1 & 2 \\
\hline 04193500 & Maumee River at Waterville, $\mathrm{OH}$ & 16,400 & Mixed & 5 & 3 \\
\hline 04208504 & Cuyahoga River at Cleveland, $\mathrm{OH}$ & 2,040 & Urban & 1 & \\
\hline 04211820 & Grand Ri at Harpersfield, $\mathrm{OH}$ & 1,430 & Mixed & 1 & \\
\hline 04213500 & Cattaraugus Creek at Gowanda, NY & 1,130 & Mixed & 1 & \\
\hline 05062500 & Wild Rice River at Twin Valley, MN & 2,410 & Mixed & 1 & \\
\hline 05082625 & Turtle River near Arvilla, ND & 658 & Agriculture & 1 & \\
\hline 05085900 & Snake River above Alvarado, MN & 566 & Agriculture & 1 & \\
\hline 05102490 & Red River of the North at Pembina, ND & 92,100 & Agriculture & 5 & \\
\hline 05288705 & Shingle Creek at Minneapolis, MN & 73 & Urban & 1 & 3 \\
\hline 05320270 & Little Cobb River near Beauford, MN & 336 & Agriculture & 1 & 2 \\
\hline 05330000 & Minnesota River near Jordan, MN & 42,000 & Agriculture & 2 & \\
\hline 05330902 & Nine Mile Creek at Bloomington, MN & 116 & Urban & 1 & \\
\hline 05331580 & Mississippi River at Hastings, MN & 96,000 & Agriculture & 5 & 3 \\
\hline 05420500 & Mississippi River at Clinton, IA & 221,700 & Mixed & 6 & 10 \\
\hline 05420680 & Wapsipinicon River near Tripoli, IA & 897 & Agriculture & & 1 \\
\hline 05449500 & Iowa River near Rowan, IA & 1,080 & Agriculture & 2 & \\
\hline 05451210 & South Fork Iowa River near New Providence, IA & 581 & Agriculture & 2 & 5 \\
\hline 05455570 & English River at Riverside, IA & 1,620 & Agriculture & 1 & \\
\hline 05464220 & Wolf Creek near Dysart, IA & 775 & Agriculture & 2 & \\
\hline 05465500 & Iowa River at Wapello, IA & 32,400 & Agriculture & 5 & 3 \\
\hline
\end{tabular}


Table 1-2. Stream sites used in the first decade (1992-2001) and second decade (2002-11) summaries.—Continued

[km², square kilometer; Cr, Creek; Ri, River; Irr Dist; Irrigation District; No., number; MA, Massachusetts; CT, Connecticut; NY, New York; NJ, New Jersey; PA, Pennsylvania; MD, Maryland; VA, Virginia; WV, West Virginia; DC, District of Columbia; NC, North Carolina; SC, South Carolina; GA, Georgia; FL, Florida; AL, Alabama; OH, Ohio; IN, Indiana; TN, Tennessee; KY, Kentucky; IL, Illinois; WI, Wisconsin; MI, Michigan; MN, Minnesota; ND, North Dakota; IA, Iowa; MT, Montana; WY, Wyoming; CO, Colorado; NE, Nebraska; MO, Missouri; AR, Arkansas; MS, Mississippi; LA, Louisiana; TX, Texas; AZ, Arizona; VT, Vermont; NV, Nevada; CA, California; WA, Washington; ID, Idaho; OR, Oregon]

\begin{tabular}{|c|c|c|c|c|c|}
\hline \multirow{2}{*}{ Site number } & \multirow{2}{*}{ Site name } & \multirow{2}{*}{$\begin{array}{l}\text { Watershed area } \\
\qquad\left(\mathrm{km}^{2}\right)\end{array}$} & \multirow{2}{*}{ Land use } & \multicolumn{2}{|c|}{ Number of years } \\
\hline & & & & $\begin{array}{c}1992- \\
2001\end{array}$ & 2002-11 \\
\hline 05490500 & Des Moines River at Keosauqua, IA & 36,400 & Agriculture & & 2 \\
\hline 05525500 & Sugar Creek at Milford, IL & 1,160 & Agriculture & 2 & \\
\hline 05531500 & Salt Creek at Western Springs, IL & 291 & Urban & 1 & 2 \\
\hline 05532500 & Des Plaines River at Riverside, IL & 1,630 & Urban & 1 & 1 \\
\hline 05553500 & Illinois River at Ottawa, IL & 28,300 & Mixed & 3 & \\
\hline 05572000 & Sangamon River at Monticello, IL & 1,430 & Agriculture & 2 & 2 \\
\hline 05584500 & La Moine River at Colmar, IL & 1,700 & Agriculture & 2 & \\
\hline 05586100 & Illinois River at Valley City, IL & 69,200 & Mixed & 5 & 6 \\
\hline 05587455 & Mississippi River Below Grafton, IL & 443,700 & Agriculture & 5 & 7 \\
\hline 06208500 & Clarks Fork Yellowstone River near Edgar, MT & 5,240 & Mixed & 1 & \\
\hline 06279500 & Bighorn River at Kane, WY & 40,800 & Mixed & 1 & \\
\hline 06295000 & Yellowstone River at Forsyth, MT & 102,000 & Mixed & 3 & 3 \\
\hline 06329500 & Yellowstone River near Sidney, MT & 177,000 & Mixed & 5 & 4 \\
\hline 06713500 & Cherry Creek at Denver, CO & 1,060 & Urban & 2 & 5 \\
\hline 06714000 & South Platte River at Denver, CO & 10,000 & Urban & 4 & \\
\hline 06753990 & Lonetree Creek near Greeley, CO & 1,480 & Agriculture & 2 & 1 \\
\hline 06754000 & South Platte River near Kersey, CO & 25,000 & Mixed & 5 & 3 \\
\hline 06795500 & Shell Creek near Columbus, NE & 762 & Agriculture & & 1 \\
\hline 06800000 & Maple Creek near Nickerson, NE & 955 & Agriculture & 5 & 5 \\
\hline 06800500 & Elkhorn River at Waterloo, NE & 18,000 & Agriculture & & 4 \\
\hline 06805500 & Platte River at Louisville, NE & 221,000 & Mixed & 7 & 8 \\
\hline 06923150 & Dousinbury Creek near Wall Street, MO & 106 & Mixed & 1 & \\
\hline 06934500 & Missouri River at Hermann, MO & $1,353,000$ & Mixed & 6 & 8 \\
\hline 07022000 & Mississippi River at Thebes, IL & $1,847,000$ & Mixed & 6 & 8 \\
\hline 07031692 & Fletcher Creek at Memphis, TN & 79 & Urban & 1 & \\
\hline 07043500 & Little River Ditch No 1 near Morehouse, MO & 1,140 & Agriculture & 2 & \\
\hline 07053250 & Yocum Creek near Oak Grove, AR & 134 & Agriculture & 1 & 1 \\
\hline 07263620 & $\begin{array}{l}\text { Arkansas River at David D Terry Lock and Dam } \\
\text { below Little Rock, AR }\end{array}$ & 401,000 & Mixed & 6 & 9 \\
\hline 07288650 & Bogue Phalia near Leland, MS & 1,300 & Agriculture & 3 & 3 \\
\hline 07288955 & Yazoo River near Long Lake, MS & 34,800 & Mixed & 6 & 10 \\
\hline 07369500 & Tensas River at Tendal, LA & 721 & Agriculture & 4 & \\
\hline 07373420 & Mississippi River near St. Francisville, LA & $2,915,000$ & Mixed & 6 & 10 \\
\hline 07374000 & Mississippi River at Baton Rouge, LA & $2,926,000$ & Mixed & & 7 \\
\hline 07374525 & Mississippi River at Belle Chasse, LA & $2,727,000$ & Mixed & & 5 \\
\hline 07375050 & Tchefuncte River near Covington, LA & 366 & Mixed & & 1 \\
\hline 07379960 & Dawson Creek at Baton Rouge, LA & 39 & Urban & 2 & 1 \\
\hline
\end{tabular}


Table 1-2. Stream sites used in the first decade (1992-2001) and second decade (2002-11) summaries.-Continued

$\left[\mathrm{km}^{2}\right.$, square kilometer; Cr, Creek; Ri, River; Irr Dist; Irrigation District; No., number; MA, Massachusetts; CT, Connecticut; NY, New York; NJ, New Jersey; PA, Pennsylvania; MD, Maryland; VA, Virginia; WV, West Virginia; DC, District of Columbia; NC, North Carolina; SC, South Carolina; GA, Georgia; FL, Florida; AL, Alabama; OH, Ohio; IN, Indiana; TN, Tennessee; KY, Kentucky; IL, Illinois; WI, Wisconsin; MI, Michigan; MN, Minnesota; ND, North Dakota; IA, Iowa; MT, Montana; WY, Wyoming; CO, Colorado; NE, Nebraska; MO, Missouri; AR, Arkansas; MS, Mississippi; LA, Louisiana; TX, Texas; AZ, Arizona; VT, Vermont; NV, Nevada; CA, California; WA, Washington; ID, Idaho; OR, Oregon]

\begin{tabular}{|c|c|c|c|c|c|}
\hline \multirow{2}{*}{ Site number } & \multirow{2}{*}{ Site name } & \multirow{2}{*}{$\begin{array}{l}\text { Watershed area } \\
\qquad\left(\mathrm{km}^{2}\right)\end{array}$} & \multirow{2}{*}{ Land use } & \multicolumn{2}{|c|}{ Number of years } \\
\hline & & & & $\begin{array}{c}1992- \\
2001\end{array}$ & 2002-11 \\
\hline 07381440 & Bayou Grosse Tete at Rosedale, LA & 305 & Agriculture & 1 & \\
\hline 07381495 & Atchafalaya River at Melville, LA & 241,700 & Mixed & 6 & 10 \\
\hline 07381590 & Wax Lake Outlet at Calumet, LA & 5,600 & Mixed & & 5 \\
\hline 07381600 & Lower Atchafalaya River at Morgan City, LA & 245,100 & Mixed & & 5 \\
\hline 08010000 & Bayou Des Cannes near Eunice, LA & 369 & Mixed & 1 & \\
\hline 08012150 & Mermentau River at Mermentau, LA & 3,580 & Agriculture & 2 & 2 \\
\hline 08012470 & Bayou Lacassine near Hayes, LA & 767 & Agriculture & 3 & \\
\hline 08049240 & Rush Creek at Arlington, TX & 74 & Urban & 1 & \\
\hline 08051500 & Clear Creek near Sanger, TX & 763 & Mixed & & 1 \\
\hline 08057200 & White Rock Creek at Dallas, TX & 173 & Urban & 2 & 5 \\
\hline 08057410 & Trinity River below Dallas, TX & 16,200 & Mixed & 5 & 7 \\
\hline 08064100 & Chambers Creek near Rice, TX & 2,140 & Mixed & 1 & 2 \\
\hline 08116650 & Brazos River near Rosharon, TX & 117,400 & Mixed & & 2 \\
\hline 08178800 & Salado Creek at San Antonio, TX & 506 & Urban & 1 & 2 \\
\hline 08180640 & Medina River at La Coste, TX & 2,100 & Mixed & 1 & \\
\hline 08181800 & San Antonio River near Elmendorf, TX & 4,530 & Urban & 2 & \\
\hline 08364000 & Rio Grande at El Paso, TX & 77,600 & Mixed & 5 & 9 \\
\hline 09153290 & Reed Wash near Mack, CO & 36 & Mixed & 1 & \\
\hline 09481740 & Santa Cruz River at Tubac, AZ & 3,120 & Urban & & 1 \\
\hline 09514000 & Buckeye Canal near Avondale, AZ & 117,000 & Mixed & 2 & \\
\hline 09517000 & Hassayampa River near Arlington, AZ & 3,970 & Mixed & 1 & 1 \\
\hline 10102200 & Cub River near Richmond, UT & 577 & Agriculture & 2 & \\
\hline 10168000 & Little Cottonwood Creek at Salt Lake City, UT & 117 & Urban & 2 & \\
\hline 10171000 & Jordan River at Salt Lake City, UT & 9,100 & Mixed & 3 & 1 \\
\hline 10350500 & Truckee River at Clark, NV & 4,310 & Mixed & 4 & 2 \\
\hline 11060400 & Warm Creek near San Bernardino, CA & 31 & Urban & 2 & \\
\hline 11074000 & Santa Ana River below Prado Dam, CA & 3,730 & Urban & & 5 \\
\hline 11075610 & Santa Ana River near Anaheim, CA & 3,870 & Urban & 2 & \\
\hline 11261100 & Salt Slough near Stevinson, CA & 1,270 & Agriculture & 2 & \\
\hline 11262900 & Mud Slough near Gustine, CA & 1,270 & Agriculture & 1 & \\
\hline 11273500 & Merced River near Newman, CA & 3,620 & Agriculture & 6 & 3 \\
\hline 11274538 & Orestimba Creek near Crows Landing, CA & 28 & Agriculture & 5 & 3 \\
\hline 11274560 & Turlock Irr Dist Lateral No. 5 near Patterson, CA & 218 & Mixed & 1 & \\
\hline 11274570 & San Joaquin River near Patterson, CA & 9,800 & Mixed & 1 & \\
\hline 11303500 & San Joaquin River near Vernalis, CA & 19,200 & Mixed & 8 & 7 \\
\hline 11390890 & Colusa Basin Drain near Knights Landing, CA & 4,260 & Agriculture & 1 & \\
\hline
\end{tabular}


Table 1-2. Stream sites used in the first decade (1992-2001) and second decade (2002-11) summaries. - Continued

$\left[\mathrm{km}^{2}\right.$, square kilometer; Cr, Creek; Ri, River; Irr Dist; Irrigation District; No., number; MA, Massachusetts; CT, Connecticut; NY, New York; NJ, New Jersey; PA, Pennsylvania; MD, Maryland; VA, Virginia; WV, West Virginia; DC, District of Columbia; NC, North Carolina; SC, South Carolina; GA, Georgia; FL, Florida; AL, Alabama; OH, Ohio; IN, Indiana; TN, Tennessee; KY, Kentucky; IL, Illinois; WI, Wisconsin; MI, Michigan; MN, Minnesota; ND, North Dakota; IA, Iowa; MT, Montana; WY, Wyoming; CO, Colorado; NE, Nebraska; MO, Missouri; AR, Arkansas; MS, Mississippi; LA, Louisiana; TX, Texas; AZ, Arizona; VT, Vermont; NV, Nevada; CA, California; WA, Washington; ID, Idaho; OR, Oregon]

\begin{tabular}{|c|c|c|c|c|c|}
\hline \multirow{2}{*}{ Site number } & \multirow{2}{*}{ Site name } & \multirow{2}{*}{$\begin{array}{l}\text { Watershed area } \\
\left(\mathbf{k m}^{2}\right)\end{array}$} & \multirow[b]{2}{*}{ Land use } & \multicolumn{2}{|c|}{ Number of years } \\
\hline & & & & $\begin{array}{c}1992- \\
2001\end{array}$ & 2002-11 \\
\hline 11447360 & Arcade Creek near Del Paso Heights, CA & 82 & Urban & 1 & 2 \\
\hline 11447650 & Sacramento River at Freeport, CA & 61,700 & Mixed & 5 & 10 \\
\hline 12113390 & Duwamish River at Tukwila, WA & 1,190 & Urban & 5 & \\
\hline 12128000 & Thornton Creek near Seattle, WA & 29 & Urban & 2 & 3 \\
\hline 12212100 & Fishtrap Creek at Lynden, WA & 99 & Mixed & 1 & \\
\hline 12424500 & Spokane River near Spokane, WA & 13,000 & Urban & 1 & \\
\hline 12464770 & Crab Creek near Ritzville, WA & 1,190 & Agriculture & & 1 \\
\hline 12471400 & Lind Coulee Wasteway near Warden, WA & 1,820 & Agriculture & 3 & \\
\hline 12472380 & Crab Creek Lateral near Othello, WA & 146 & Agriculture & 1 & \\
\hline 12473740 & El 68 D Wasteway near Othello, WA & 377 & Agriculture & 1 & \\
\hline 12500420 & Moxee Drain near Union Gap, WA & 353 & Mixed & 1 & \\
\hline 12505450 & Granger Drain at Granger, WA & 160 & Agriculture & 1 & 4 \\
\hline 12510500 & Yakima River at Kiona, WA & 14,500 & Mixed & 1 & 3 \\
\hline 13055000 & Teton River near St Anthony, ID & 2,290 & Mixed & 1 & 1 \\
\hline 13092747 & Rock Creek at Twin Falls, ID & 623 & Agriculture & 5 & 2 \\
\hline 13154500 & Snake River at King Hill, ID & 92,900 & Mixed & 5 & 6 \\
\hline 13351000 & Palouse River at Hooper, WA & 6,380 & Agriculture & 8 & 2 \\
\hline 14201300 & Zollner Creek near Mt. Angel, OR & 39 & Agriculture & & 3 \\
\hline 14202000 & Pudding River at Aurora, OR & 1,260 & Agriculture & 1 & \\
\hline 14206950 & Fanno Creek at Durham, OR & 81 & Urban & & 5 \\
\hline 14211720 & Willamette River at Portland, OR & 28,900 & Mixed & 6 & 9 \\
\hline 040863075 & $\begin{array}{l}\text { North Branch Milwaukee River near Random } \\
\text { Lake, WI }\end{array}$ & 130 & Agriculture & 1 & \\
\hline 040869415 & Lincoln Creek at Milwaukee, WI & 26 & Urban & & 5 \\
\hline 073814675 & Bayou Boeuf at Amelia, LA & 3,170 & Mixed & 1 & \\
\hline 094196783 & Las Vegas Wash near Las Vegas, NV & 2,650 & Urban & 5 & 5 \\
\hline 0242354750 & Cahaba Valley Creek at Pelham, AL & 66 & Urban & 2 & 3 \\
\hline 0357479650 & Hester Creek near Plevna, AL & 76 & Agriculture & 2 & 1 \\
\hline 252414080333200 & C-111 Canal near Homestead, FL & 132 & Mixed & 1 & \\
\hline 322023090544500 & Mississippi River above Vicksburg, MS & $2,929,500$ & Mixed & & 1 \\
\hline 393944084120700 & Holes Creek at Kettering, $\mathrm{OH}$ & 52 & Urban & 2 & 2 \\
\hline 394340085524601 & Sugar Creek at New Palestine, IN & 246 & Agriculture & 7 & 5 \\
\hline
\end{tabular}






\section{递}

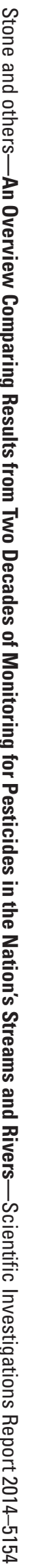

